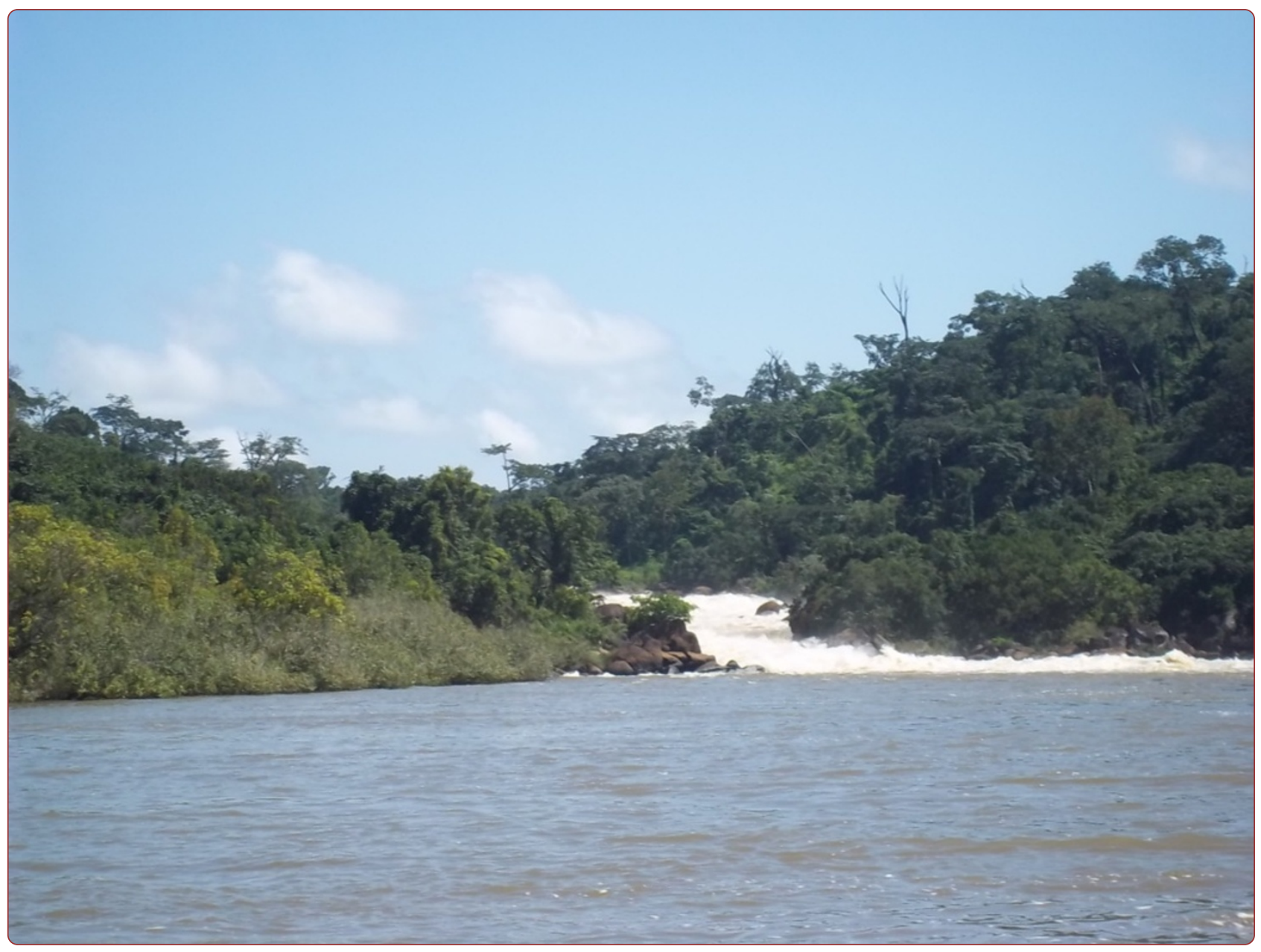

Wildlife use and the role of taboos in the conservation of wildlife around the Nkwende Hills Forest Reserve; South-west Cameroon

Bobo et al. 


\title{
Wildlife use and the role of taboos in the conservation of wildlife around the Nkwende Hills Forest Reserve; South-west Cameroon
}

\author{
Kadiri Serge Bobo ${ }^{1,2^{*}}$, Fodjou Florence Mariam Aghomo ${ }^{1}$ and Bonito Chia Ntumwel ${ }^{1}$
}

\begin{abstract}
Background: Cameroon is known as Africa in miniature because of its multitude of ecosystems and associated biodiversity, cultures and traditions. The country also harbors very ancient human populations whose relationship with nature is very intimate and where animals play important roles for their livelihood. Located in the South-west region of Cameroon, the Nkwende Hills Forest Reserve (NHFR) represents an important wildlife conservation site because of its strategic position at the periphery of Korup National Park (KNP). The periphery of NHFR is inhabited by several ethnic groups amongst which are the Obang and Ngunnchang clans who share particular relationships with wildlife. The present paper studies these relationships and contributes to the growing trend of scientific ethnozoological studies across Africa.
\end{abstract}

Method: From August to December 2011, a questionnaire survey was addressed to 126 randomly chosen household respondents (HRs) in seven villages at the Northwest periphery of NHFR. In households, preference was given to parents, and to the eldest child in case the parents were absent. Questions related to the uses and local taboos on wildlife species were asked to HRs.

Results: Both communities have accumulated knowledge on the use of 51 wildlife species of which $50.9 \%$ represent mammals, 21.6\% birds, 15.7\% reptiles, 7.8\% fish and 3.9\% invertebrates. Four main use categories of wildlife by both communities were identified, namely (1) Food, medicine and sales values (41.2\%), (2) Ethnomusical animals and parts used as trophy (29.2\%), (3) Decoration and jewelry making values (21.9\%) and (4) Magico-religious and multipurpose values (7.8\%). Regarding local taboos, species specific taboos (generation totems and acquired totems), habitat taboos (sacred forests), method and segment taboos still persist but are rarely respected among the youth mainly because of the scarcity of wildlife (65.3\% of HRs).

Conclusion: Like other communities living around forest areas, the studied communities use wildlife in their culture and tradition. Wildlife is not only used for consumption, but also for traditional medicines, craft materials and spiritual purposes. But, threats to wildlife and their traditional uses are real and acculturation seems to be the main driver. High priority should be given to the reconciling conservation of species with high values for local communities and human needs.

Keywords: Cameroon, Culture, Ngunnchang and Obang communities, Nkwende hill forest reserve, Taboos, Traditional ecological knowledge, Wildlife

\footnotetext{
* Correspondence: bobokadiris@yahoo.com

'Department of Forestry, Faculty of Agronomy and Agricultural Sciences, University of Dschang, P.O. Box: 222, Dschang, Cameroon

${ }^{2}$ School for the Training of Wildlife Specialists Garoua, Ministry of Forestry and Wildlife, P.O. Box: 271, Garoua, Cameroon
}

\section{Biomed Central}

(c) 2014 Bobo et al.; licensee BioMed Central. This is an Open Access article distributed under the terms of the Creative Commons Attribution License (http://creativecommons.org/licenses/by/4.0), which permits unrestricted use, distribution, and reproduction in any medium, provided the original work is properly credited. The Creative Commons Public Domain Dedication waiver (http://creativecommons.org/publicdomain/zero/1.0/) applies to the data made available in this article, unless otherwise stated. 


\section{Background}

Tropical evergreen forests are the most species-rich ecological ecosystems and are highly endangered all over the world [1]. According to [2-5], Cameroon forests are primordial for the conservation of African biodiversity, but continue to face alarming threats. Some of these threats are closely related to people's dependency on Non Timber Forest Products for their livelihoods [6-8]. Taking into account the importance of biodiversity in our communities today [9], integrated conservation measures for sustainable management seems to be the best solution $[10,11]$. The adoption of such measures requires

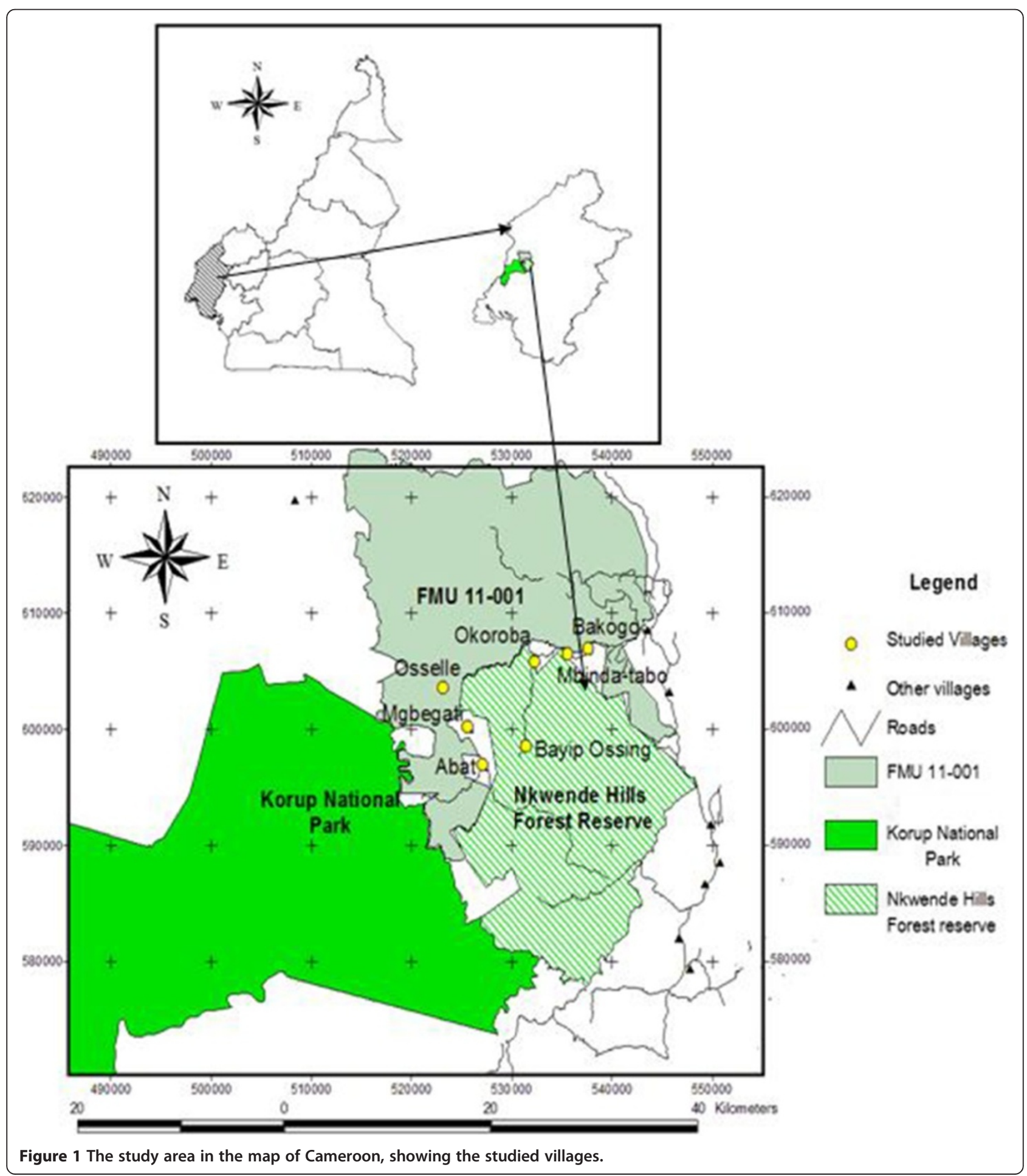




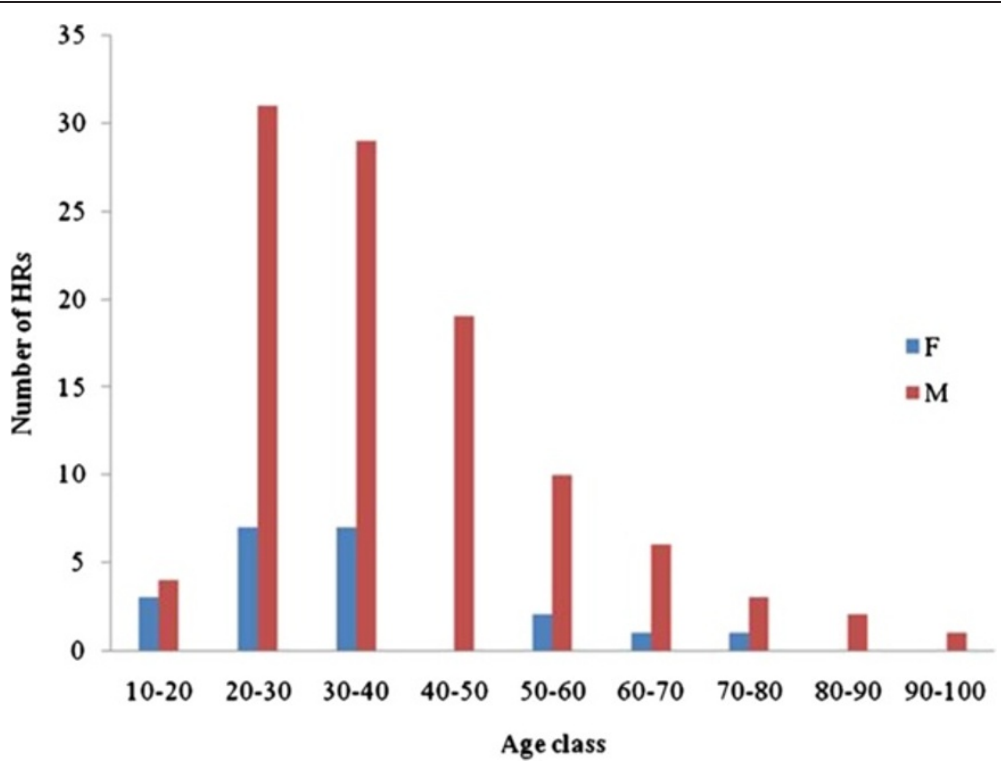

Figure 2 Distribution of HRs per gender and age.

knowledge from local populations who are the principal indicators of the changes observed in their area [12]. Ethnobiology helps adapt a link between natural resources and local populations and requires two basic components i.e. the knowledge on biodiversity and its uses (mammals, birds, reptiles and amphibians) and a comprehension of the culture $[13,14]$. It has been demonstrated that these uses are generally guided by laws and restrictions important for conservation $[15,16]$. Several studies have shown how these uses, cultures and traditions lead to wildlife conservation $[13,17,18]$. Also,

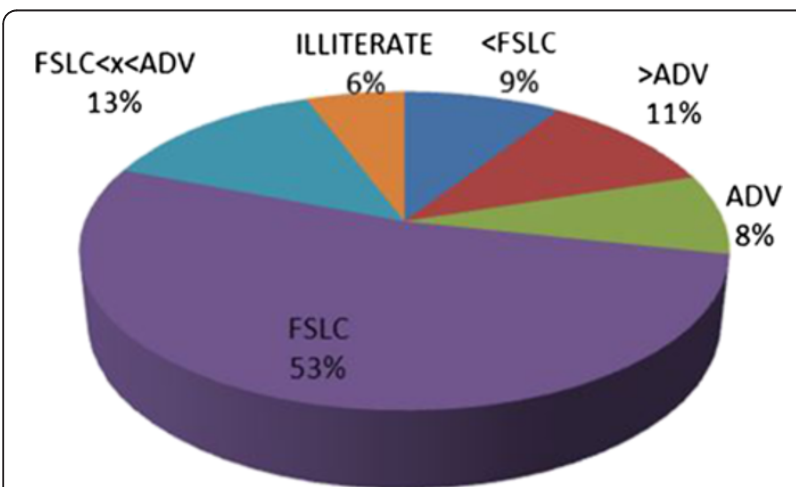

Figure 3 Distribution of HRs by level of education. Notes: FSLC refers to HRs who are holders of the First School Leaving Certificate; ADV refers to HRs who are holders of a General Certificate of Education Advanced Level and ILLITERATES refers to HRs who have not been to school; FSLC $<X<$ ADV refers to HRs who attended secondary education but did not obtain the ADV; $\angle F S L C$ refers to HRs who attended primary education but did not obtain a FSLC; $>$ ADV refers to HRs who attended higher education after the ADV. the culture and tradition regulate the use of certain species especially those of nutritional and medicinal importance [19-22]. Ethnozoological studies can be a valuable asset to increase our understanding of the economic, cultural, social, and traditional roles played by animals and reconcile human and conservation needs. In this context, they have a central role in conservation and management [23]. Increased consideration for traditional uses of wildlife will help solve important conservation problems related to human-wildlife conflicts [24]. Therefore, to secure a future for animal populations, conservationists must understand not only the ecological, but also the cultural and economic interactions that link ecological and social systems [25]. Furthermore, there is a great need for ethnobiological studies in Cameroon given the increasing relevance of this science across Africa. The present paper documents traditional uses and cultural values of wildlife for local populations, and the contribution of taboos to wildlife conservation around the NHFR.

\section{Methods}

\section{Study area}

The present study was carried out in seven villages (Abat, Mgbegati, Bayib-ossing, Osselle, Okoroba, Mbinda-Tabo and Bakogo) situated in the support zone of KNP, specifically between the Northwestern part of NHFR and Northeastern part of KNP, in the Southwest region of Cameroon (Figure 1). The name "Nkwende" in Ejagham tribe, meaning "a water source for animals", was given to those hills in 1960. The Nkwende hills lie to the Northwest of Nguti town and to the West of Nguti- 


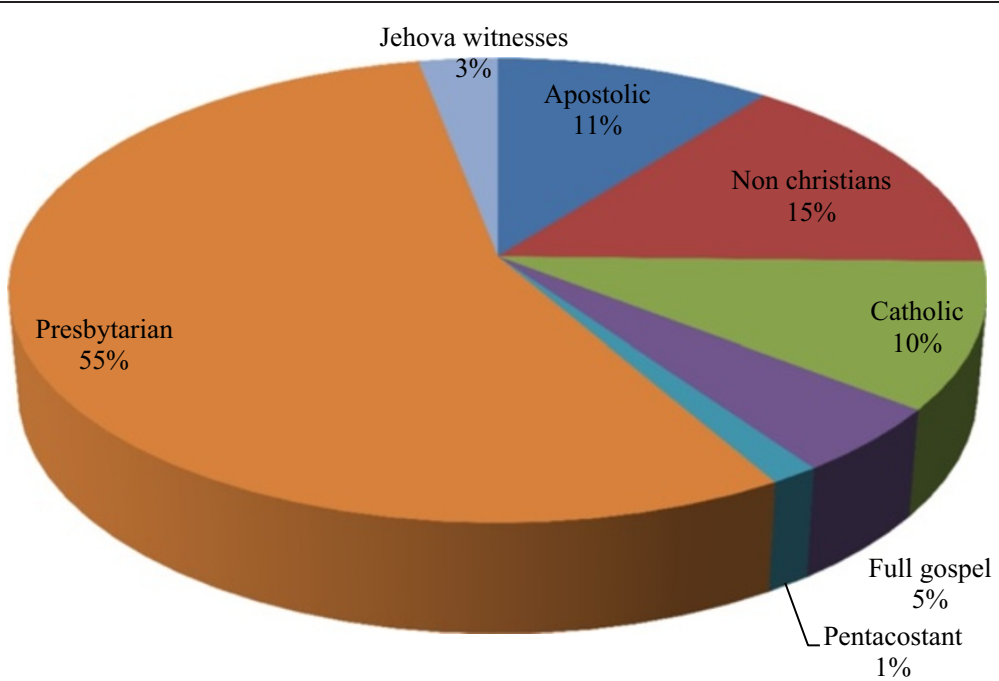

Figure 4 Distribution of HRs per religion.

Mamfe road. The highest peak is about $737 \mathrm{~m}$ asl around Bayib-Ossing village [26]. Part of NHFR extends to Okoroba village recognisable by rock faces commonly called by the locals "chimpanzee stone", alleged to be a refuge for chimpanzees. The forest at present is a secondary forest in the surrounding villages due to logging and agricultural activities. Intact primary forests still exist in higher altitudes where no suitable timber trees were found or where the sloppy nature of the hills made forest exploitation impossible [26].

Due to its proximity to KNP, the study area shares similar climatic, fauna and flora characteristics. The rainfall is about $5000 \mathrm{~mm}$ per year and the mean annual temperature is about $25^{\circ} \mathrm{C}$ [27]. The large mammal fauna of KNP consists of 33 families with 161 species. KNP contains one quarter of all Africa's primate species and represents an important site for primate conservation. It contains species with restricted distribution including a number of endemics such as the giant otter shrew Potamogale velox, Calabar angwantibo Arctocebus calabarensis, drill Mandrillus leucophaeus, and Preuss's red colobus Procolobus preussi. Concerning small mammals, Korup contains as many as 55 species of bats and 47 species of rodents. Here, the presence of three shrews (Crocidura crenata, C. grandiceps and C. lamottei) were recorded for the first time in Cameroon and a new

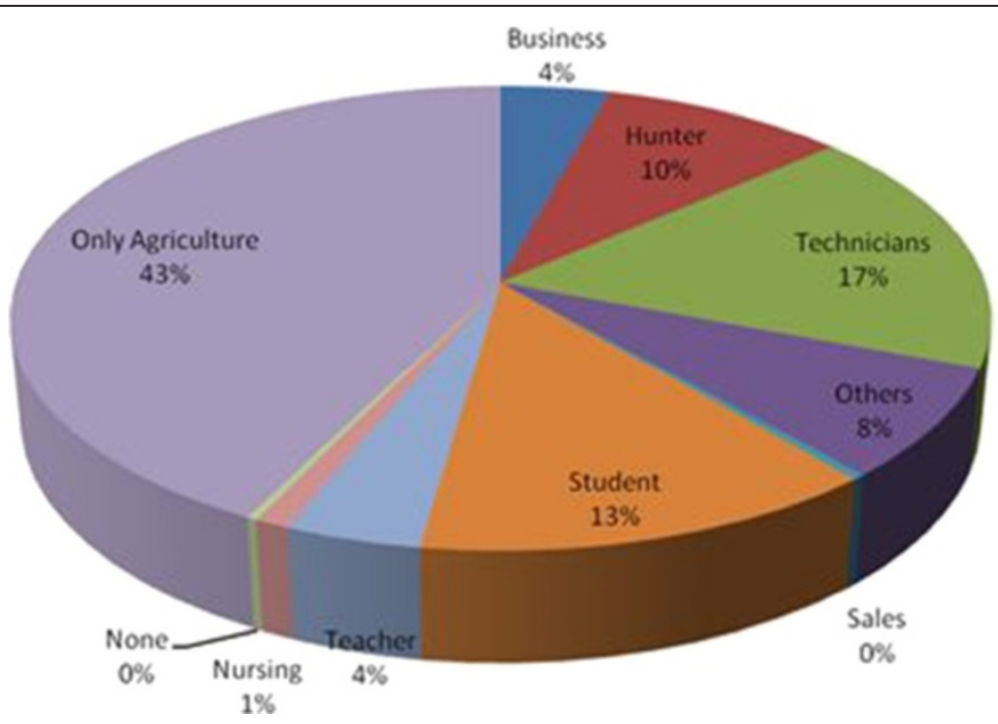

Figure 5 Distribution of HRs per economic activity. 
Table 1 Mammals parts used and reasons

\begin{tabular}{|c|c|c|c|}
\hline Animal & Part used & Use(s) and use method(s) & Reason(s) \\
\hline \multirow{4}{*}{$\begin{array}{l}\text { Peter's duiker Cephalophus } \\
\text { callipygus }\end{array}$} & Teeth $^{3}$ & - Design necklaces & For prestige \\
\hline & \multirow[t]{2}{*}{ Skin 2,3} & - Making of drums & $\begin{array}{l}\text { Durable, produces the desired sound, easily } \\
\text { malleable and it is an inherited practice from } \\
\text { the elders. Also, the skin is not good for } \\
\text { consumption. }\end{array}$ \\
\hline & & $\begin{array}{l}\text { - Decorating houses of Ekpe society } \\
\text { members during liberation ceremonies }\end{array}$ & Traditional inherited practice \\
\hline & Meat ${ }^{1}$ & $\begin{array}{l}\text { - Consumed by pregnant women for } \\
\text { blood regeneration }\end{array}$ & For better development of the foetus \\
\hline \multirow{11}{*}{$\begin{array}{l}\text { African forest buffalo } \\
\text { Syncerus caffer }\end{array}$} & \multirow{4}{*}{$\begin{array}{l}\text { Horn } \\
\text { (Figure 6) }\end{array}$} & - Musical instrument & Announcing bad news \\
\hline & & $\begin{array}{l}\text { - For drinking wine (traditional cup) } \\
\text { (see also [48]) }\end{array}$ & Has the shape of a cup \\
\hline & & - Sold to Nigerians & For money \\
\hline & & - Design necklaces & Traditional inherited practice \\
\hline & Skull ${ }^{3}$ & - Decoration & Traditional inherited practice \\
\hline & \multirow[t]{2}{*}{ Bones $^{1,4}$} & - Used by sorcerers & Not revealed \\
\hline & & $\begin{array}{l}\text { - Treats goiter: grind the bones and mix with } \\
\text { palm kernel oil (manyanga) and apply on } \\
\text { goiter locally called "nkongho illness" }\end{array}$ & Medicinal \\
\hline & $\operatorname{Limbs}^{1}$ & $\begin{array}{l}\text { - Treats abscesses: mix with oil palm and } \\
\text { apply on abscess }\end{array}$ & Medicinal \\
\hline & \multirow[t]{2}{*}{ Skin 2,3} & - Making of drums & Resistant \\
\hline & & - Decoration & $\begin{array}{l}\text { Shows hierarchy between members of the } \\
\text { Ekpe society }\end{array}$ \\
\hline & Meat ${ }^{1}$ & - Consumed & Believed to treat goiter patients \\
\hline $\begin{array}{l}\text { Yellow back duiker } \\
\text { Cephalophus sylvicultor }\end{array}$ & Skin $^{1}$ & $\begin{array}{l}\text { - Treat skin inflammations: apply on } \\
\text { swollen parts }\end{array}$ & Medicinal \\
\hline \multirow[t]{2}{*}{$\begin{array}{l}\text { Bay duiker Cephalophus } \\
\text { dorsalis }\end{array}$} & \multirow[t]{2}{*}{ Skin ${ }^{2,3}$} & $\begin{array}{l}\text { - Decorate the seat of the chief of } \\
\text { Ekpe society }\end{array}$ & Denotes hierarchy \\
\hline & & - Making of drums & Resistant \\
\hline \multirow[t]{9}{*}{$\begin{array}{l}\text { Blue duiker Cephalophus } \\
\text { monticola }\end{array}$} & Skull ${ }^{1,3}$ & $\begin{array}{l}\text { - Sold to Nigerians and used to design } \\
\text { necklaces }\end{array}$ & For money \\
\hline & Jaws $^{1}$ & $\begin{array}{l}\text { - Treats tooth ache and intestinal worm } \\
\text { problems: burn, grind and mix with leaves } \\
\text { of Aframomum melegueta locally called } \\
\text { "alakata pepper" }\end{array}$ & Medicinal \\
\hline & Bones $^{1}$ & - Sold to Nigerians & For money \\
\hline & \multirow[t]{2}{*}{$\operatorname{Skin}^{2}$} & - Making of drums (Figure 7) & $\begin{array}{l}\text { Elastic, easily malleable, has little or no fats, } \\
\text { light, durable and resistant }\end{array}$ \\
\hline & & $\begin{array}{l}\text { - Decorate the seat of the chief of Ekpe } \\
\text { society }\end{array}$ & Denotes hierarchy \\
\hline & Hoofs $^{1}$ & - For purging children & Renders the child strong and active \\
\hline & \multirow[t]{3}{*}{ Meat ${ }^{1,4}$} & $\begin{array}{l}\text { - For liberation ceremonies: cook with } \\
\text { plantains Musa sp.; and/or cassava } \\
\text { Manihot esculenta and given to ancestors }\end{array}$ & $\begin{array}{l}\text { Considered as a dead animal and can link } \\
\text { the living to the dead }\end{array}$ \\
\hline & & - Marriage ceremonies: cook with plantains & Traditional inherited practice \\
\hline & & $\begin{array}{l}\text { - Consume during death and traditional } \\
\text { dance ceremonies }\end{array}$ & Easily hunted \\
\hline
\end{tabular}


Table 1 Mammals parts used and reasons (Continued)

\begin{tabular}{|c|c|c|c|}
\hline \multirow[t]{8}{*}{$\begin{array}{l}\text { Ogilby's duiker } \\
\text { Cephalophus ogilbyi }\end{array}$} & $\begin{array}{l}\text { Horn, tail limbs, } \\
\text { Skull and hoofs }\end{array}$ & $\begin{array}{l}\text { - Sold to Nigerians } \\
\text { - Decoration }\end{array}$ & Traditional inherited practice \\
\hline & Skull ${ }^{1}$ & $\begin{array}{l}\text { - Treats frontal headache: burn, grind and } \\
\text { apply on the forehead }\end{array}$ & Medicinal \\
\hline & $\begin{array}{l}\text { Oil from the } \\
\text { bones }^{1}\end{array}$ & - Treats inflammations: apply on swollen parts & Medicinal \\
\hline & $J^{\prime a w s}{ }^{1}$ & $\begin{array}{l}\text { - Treats toothache and intestinal worms: burn, } \\
\text { grind and mix with Aframomum melegueta } \\
\text { and consume }\end{array}$ & Medicinal \\
\hline & \multirow[t]{2}{*}{ Bones $^{1,2}$} & $\begin{array}{l}\text { - Musical instrument: used together with the } \\
\text { shell of tortoise }\end{array}$ & The bones are big \\
\hline & & - Sold to Nigerians & For money \\
\hline & Skin $^{2}$ & - Making of drums & $\begin{array}{l}\text { Produces a good and desired sound, durable, } \\
\text { light and elastic. Has no fats and the skin is } \\
\text { not good for consumption }\end{array}$ \\
\hline & Meat $^{4}$ & $\begin{array}{l}\text { - For liberation, marriage and death ceremonies } \\
\text { to appease and communicate with ancestors: } \\
\text { during such ceremonies, it is cooked with plantains. } \\
\text { During incantations, part of the meal is poured on } \\
\text { the ground (around graves, sacred sites) together } \\
\text { with palm wine (Raphia sp.;), oil palm, water, tobacco, } \\
\text { cola nuts (Cola acuminate) and coins }\end{array}$ & $\begin{array}{l}\text { It is considered as the incarnation of } \\
\text { dead people and can act as a mean of } \\
\text { communication between the living and } \\
\text { the spirits of deaths. It is also used because } \\
\text { goats are scarce and very expensive }\end{array}$ \\
\hline \multirow{2}{*}{$\begin{array}{l}\text { Red-capped mangabey } \\
\text { Cercocebus torquatus }\end{array}$} & Skull $^{1}$ & - Sold to Nigerians & For money \\
\hline & Head $^{1}$ & $\begin{array}{l}\text { - Treats tuberculosis: burn, grind and mix with oil } \\
\text { palm and consume }\end{array}$ & Medicinal \\
\hline $\begin{array}{l}\text { Hammered bat Hypsignathus } \\
\text { monstrosus }\end{array}$ & Fur $^{1}$ & - Treats burns: plaster on the burned parts & Medicinal \\
\hline \multirow{5}{*}{$\begin{array}{l}\text { Water chevrotain } \\
\text { Hyemoschus aquaticus }\end{array}$} & $\operatorname{Limbs}^{1}$ & - Sold to Nigerians and to tradi-practitioners & For money \\
\hline & Bones of limbs ${ }^{1}$ & - Treats fractures: apply on fractures of the legs & Medicinal \\
\hline & Skin $^{2}$ & - Making of drums & Resistant and produces the desired sound \\
\hline & Veins of limbs ${ }^{1}$ & $\begin{array}{l}\text { - Treats paralyses: mix with roots of Aframomum } \\
\text { melegueta. The paste produced is applied on cuts } \\
\text { made on the body using the teeth of viper }\end{array}$ & Medicinal \\
\hline & Meat $^{4}$ & $\begin{array}{l}\text { - Liberation ceremonies: cooked with Ogilby's } \\
\text { duiker and other medicines. During incantations, } \\
\text { part of the meal is poured on the ground around } \\
\text { graves, sacred sites }\end{array}$ & Traditional inherited practice \\
\hline \multirow{9}{*}{$\begin{array}{l}\text { Ellioti chimpanzee Pan } \\
\text { troglodytes }\end{array}$} & \multirow{2}{*}{$\begin{array}{l}\text { Skull, bones and } \\
\text { limbs }^{1}\end{array}$} & - Sold to Nigerians & For money \\
\hline & & $\begin{array}{l}\text { - Fortify men: grind and mix with Aframomum } \\
\text { melegueta, and applied on cuts made on the } \\
\text { body with a razor blade }\end{array}$ & Believed to be a strong animal \\
\hline & Skull ${ }^{3}$ & - Making of necklaces & For money \\
\hline & $\begin{array}{l}\text { Hands and } \\
\operatorname{limbs}^{4}\end{array}$ & - Consume mainly by chiefs & Not revealed \\
\hline & \multirow[t]{3}{*}{ Bones $^{1}$} & - Consume by pregnant women & Believed to be a strong animal \\
\hline & & $\begin{array}{l}\text { - Fortify man: grind and mix with Aframomum } \\
\text { melegueta, water and leaves of Ageratum cornisoides } \\
\text { and applied on body cuts }\end{array}$ & Believed to be a strong animal \\
\hline & & $\begin{array}{l}\text { - Fortify children: purge by pregnant women } \\
\text { and apply on body cuts made on children }\end{array}$ & Believed to be a strong animal \\
\hline & Skin $^{2}$ & - Making of drums & Resistant to stress \\
\hline & Meat $^{4}$ & & Traditional inherited practice \\
\hline
\end{tabular}


Table 1 Mammals parts used and reasons (Continued)

\begin{tabular}{|c|c|c|c|}
\hline & & $\begin{array}{l}\text { - For death, marriage and cultural ceremonies: } \\
\text { cook in meals }\end{array}$ & \\
\hline \multirow[t]{11}{*}{$\begin{array}{l}\text { African civet Civettictis } \\
\text { civetta }\end{array}$} & Anus $^{1}$ & $\begin{array}{l}\text { - Treats convulsions: inhaled by children because } \\
\text { of its pronounced odour }\end{array}$ & Medicinal \\
\hline & Nails ${ }^{4}$ & $\begin{array}{l}\text { - Close two mystical of the four eyes of sorcerers: } \\
\text { mix with Ageratum cornisoides and perform rituals }\end{array}$ & Deliverance from evil \\
\hline & $\operatorname{Limbs}^{1}$ & $\begin{array}{l}\text { Ease walking of children: mix with herbs and } \\
\text { purge into children }\end{array}$ & Medicinal \\
\hline & $\mathrm{Skin}^{2,3,4}$ & $\begin{array}{l}\text { - Decoration: hang in houses of members of } \\
\text { Ekpe society (Figure 8) }\end{array}$ & $\begin{array}{l}\text { Strong and prestigious animal and can be used } \\
\text { in replacement of the skin of the leopard }\end{array}$ \\
\hline & & & $\begin{array}{l}\text { Denotes hierarchy between the members } \\
\text { of Ekpe society }\end{array}$ \\
\hline & & - Making of drums & $\begin{array}{l}\text { Gives the desired sound since it is thick and } \\
\text { resistant }\end{array}$ \\
\hline & & - Used as a carpet by chiefs and elders & $\begin{array}{l}\text { Demonstrates hierarchy between members } \\
\text { of Ekpe }\end{array}$ \\
\hline & & $\begin{array}{l}\text { - For initiation ceremonies and decoration of the } \\
\text { chair of the chief of Ekpe }\end{array}$ & Replaces the skin of the leopard \\
\hline & Fur $^{1}$ & $\begin{array}{l}\text { - Treats convulsions: apply on the eyes of children } \\
\text { with palm kernel oil }\end{array}$ & Medicinal \\
\hline & Tail $^{3}$ & - Decoration & Traditional inherited practice \\
\hline & Testes $^{1}$ & $\begin{array}{l}\text { - Treats sexual weakness of men: grind and mix } \\
\text { with leaves of «besug-etig» }\end{array}$ & Medicinal \\
\hline \multirow[t]{8}{*}{$\begin{array}{l}\text { Preuss's red colobus } \\
\text { Procolobus preussi }\end{array}$} & Skull ${ }^{1}$ & $\begin{array}{l}\text { - Treats cough/tuberculosis: burn, grind, mix with } \\
\text { oil palm and consume }\end{array}$ & Medicinal \\
\hline & & - Sold to Nigerians & For money \\
\hline & Bones $^{1}$ & $\begin{array}{l}\text { - Renders man strong and active: grind and apply } \\
\text { on cuts made on the skin }\end{array}$ & Believed to be a strong animal \\
\hline & Bones of limbs ${ }^{1}$ & $\begin{array}{l}\text { - Fortify children: grind and mix with leaves (locally } \\
\text { called «Njichondick» or blood leaves). The resulting } \\
\text { solution is purged by pregnant women }\end{array}$ & Believed to be a strong animal \\
\hline & Limbs and head $^{1}$ & - Sold to Nigerians & For money \\
\hline & Skin ${ }^{2}$ & - Making of drums & Resistant \\
\hline & Fur $^{1}$ & $\begin{array}{l}\text { - Treats skin burns and dries fresh wounds: } \\
\text { plaster on the burned part }\end{array}$ & Medicinal \\
\hline & & $\begin{array}{l}\text { - Treats cough: mix with oil palm, Ageratum } \\
\text { cornisoides and the coat of palm kernel fruits } \\
\text { and consume }\end{array}$ & Medicinal \\
\hline $\begin{array}{l}\text { Western tree hyrax } \\
\text { Dendrohyrax dorsalis }\end{array}$ & Skin $^{2}$ & - Making of drums & Light and easily malleable \\
\hline \multirow[t]{5}{*}{ Drill Mandrillus leucophaeus } & Skull and limbs ${ }^{1}$ & - Sold to Nigerians & For money \\
\hline & Teeth $^{3}$ & - Making necklaces & For prestige \\
\hline & Bones $^{1,2}$ & - For drumming & Traditional inherited practice \\
\hline & & $\begin{array}{l}\text { - Treats fractures: tie around fractured hand } \\
\text { or leg }\end{array}$ & Medicinal \\
\hline & Skin $^{2}$ & - Making of drums & Gives a good sound, resistant and thick \\
\hline Flying squirrel Funisciurus sp:; & Fur ${ }^{1}$ (Figure 9) & $\begin{array}{l}\text { Treats fire burns and dries fresh wounds: plaster } \\
\text { on the burned part and wounds }\end{array}$ & Medicinal \\
\hline \multirow{3}{*}{$\begin{array}{l}\text { Tropical forest elephant } \\
\text { Loxodonta cyclotis }\end{array}$} & Dung $^{1}$ & - Treats stomachache: consume & Medicinal \\
\hline & & - Treats sterility in women: consume & Medicinal \\
\hline & Hoofs $^{1}$ & $\begin{array}{l}\text { - Treats elephantiasis: cut into seven parts, and } \\
\text { burned then mixed with wood ash. The } \\
\text { infected leg is cut using a razor blade }\end{array}$ & Medicinal \\
\hline
\end{tabular}


Table 1 Mammals parts used and reasons (Continued)

\begin{tabular}{|c|c|c|c|}
\hline & & $\begin{array}{l}\text { and placed on the smoke produced } \\
\text { by the fire in which the hoofs are being } \\
\text { burned. This is done for seven days }\end{array}$ & \\
\hline & \multirow[t]{4}{*}{ Tusks $^{1,3,4}$} & - Sold to Nigerians & For money \\
\hline & & - Making necklaces and jewelry & For chiefs and elders \\
\hline & & - Decoration & For prestige \\
\hline & & - Protection & Traditional inherited practice \\
\hline & \multirow[t]{2}{*}{ Bones $^{1}$} & $\begin{array}{l}\text { - Treats waist pains: grind, mix with the bone } \\
\text { marrow and apply on cuts made on the waist } \\
\text { with a razor blade }\end{array}$ & Medicinal \\
\hline & & - Sold to Nigerians & For money \\
\hline & Skin of the ear ${ }^{2}$ & - Making of drums & Solid, durable, resistant and elastic \\
\hline & Tail fur ${ }^{3}$ & - Decorate the cap of chiefs & For prestige \\
\hline & Meat $^{4}$ & - Liberation ceremonies & Not revealed \\
\hline \multirow[t]{7}{*}{$\begin{array}{l}\text { Western gorilla Gorilla } \\
\text { gorilla }\end{array}$} & $\begin{array}{l}\text { Skull and limb } \\
\text { bones }^{1}\end{array}$ & - Sold to Nigerians & For money \\
\hline & \multirow[t]{4}{*}{$\begin{array}{l}\text { Right hand } \\
\text { bones } s^{1,2}\end{array}$} & $\begin{array}{l}\text { - Fortify man: grind and mix with palm oil then } \\
\text { apply on cuts made on the body with a razor blade }\end{array}$ & Believed to be a strong animal \\
\hline & & $\begin{array}{l}\text { - Fortify babies and children: grind and mix with } \\
\text { seeds of Aframomum melegueta and used for } \\
\text { purging pregnant women }\end{array}$ & Believed to be a strong animal \\
\hline & & - For drumming & Traditional inherited practice \\
\hline & & - Fortify children: massage of children & Believed that the gorilla is a strong animal \\
\hline & Skin $^{2}$ & - Making of drums & Produces quality sound \\
\hline & Meat ${ }^{1}$ & - Fortify foetus: consume by pregnant women & Believed to be a strong animal \\
\hline $\begin{array}{l}\text { Putty nosed Guenon } \\
\text { Cercopithecus nictitans }\end{array}$ & Skin ${ }^{2}$ & - Making of drums & $\begin{array}{l}\text { Resistant, produces quality sound and } \\
\text { it is elastic }\end{array}$ \\
\hline \multirow[t]{8}{*}{ Leopard Panthera pardus } & \multirow[t]{2}{*}{ Teeth ${ }^{3,4}$} & - Decoration & Traditional inherited practice \\
\hline & & - Protection: wear as necklaces by chiefs & Traditional inherited practice \\
\hline & Limbs $^{1}$ & $\begin{array}{l}\text { - Fortify foetus: grind and mix with cold water } \\
\text { and ground roasted plantains. The resulting } \\
\text { concoction is purged by pregnant women }\end{array}$ & Believed to be a strong animal \\
\hline & \multirow[t]{5}{*}{ Skin $^{3}$} & - Decoration of homes of Ekpe members & $\begin{array}{l}\text { Signifies prestige and denotes hierarchy } \\
\text { between members of Ekpe society }\end{array}$ \\
\hline & & - Dressing & Hierarchy \\
\hline & & - Making drums played only by Ekpe members & $\begin{array}{l}\text { Shows strength of the society and produces } \\
\text { quality sound }\end{array}$ \\
\hline & & - Sold to Nigerians and village chiefs & For money \\
\hline & & $\begin{array}{l}\text { - As carpet and for decorating the chair of the } \\
\text { chief of Ekpe society }\end{array}$ & Traditional inherited practice \\
\hline $\begin{array}{l}\text { Marsh mongoose Atilax } \\
\text { paludinosus }\end{array}$ & Teeth $^{1}$ & $\begin{array}{l}\text { - Treats snake bites: used as a blade to wound } \\
\text { the bitten part before applying the remedy }\end{array}$ & Medicinal tool \\
\hline \multirow[t]{2}{*}{$\begin{array}{l}\text { Mona guenon Cercopithecus } \\
\text { mona }\end{array}$} & Skull ${ }^{1}$ & $\begin{array}{l}\text { - Treats whooping cough: burn, grind and mix } \\
\text { with oil palm and consume by children }\end{array}$ & Medicinal \\
\hline & Bones $^{4}$ & $\begin{array}{l}\text { - For charming: mix small pieces with roots of } \\
\text { Mimosa invisa and put into the pocket. Then } \\
\text { call the name of the desired person several times }\end{array}$ & Traditional inherited practice \\
\hline \multirow{3}{*}{$\begin{array}{l}\text { African palm civet Nandinia } \\
\text { binotata }\end{array}$} & \multirow[t]{2}{*}{ Skin $^{2}$} & - Making of drums & Produces quality sound \\
\hline & & $\begin{array}{l}\text { - Decoration: hang in the room of a dead member } \\
\text { of the Ekpe society in substitution of the skin of a } \\
\text { leopard (Figure 10) }\end{array}$ & Denotes hierarchy between members of Ekpe \\
\hline & Tail $^{4}$ & & Traditional inherited practice \\
\hline
\end{tabular}


Table 1 Mammals parts used and reasons (Continued)

\begin{tabular}{|c|c|c|c|}
\hline & & $\begin{array}{l}\text { - Tie on the hands of women (those who have } \\
\text { been proposed marriage) during the 'monenkim' } \\
\text { traditional dance (dance of women) (Figure 11) }\end{array}$ & \\
\hline & & - As a scarecrow when drying cocoa & For scaring birds and domestic animals \\
\hline & Fur1 & $\begin{array}{l}\text { - Treating fire burns: burn, grind and mix with } \\
\text { leaves of Aframomum melegueta and apply on } \\
\text { the burned part }\end{array}$ & Medicinal \\
\hline & Head ${ }^{1}$ & - Sold to Nigerians & For money \\
\hline Pangolin Phataginus & Scales $^{4}$ & - Blade & It is sharp \\
\hline $\begin{array}{l}\text { tricuspis/Uronamis } \\
\text { tetradactyla }\end{array}$ & Skin $^{2}$ & - Making of drums & $\begin{array}{l}\text { Produces quality sound, not good for } \\
\text { consumption }\end{array}$ \\
\hline & Meat $^{4}$ & $\begin{array}{l}\text { - Seduction: very appreciated by women when } \\
\text { cooked }\end{array}$ & It is believed that the fat attracts women \\
\hline $\begin{array}{l}\text { Brushed-tailed porcupine } \\
\text { Atherurus africanus }\end{array}$ & Spines ${ }^{3,4}$ & $\begin{array}{l}\text { - Decorating the caps of members of Ekpe } \\
\text { (Figure 12) }\end{array}$ & $\begin{array}{l}\text { Heritage and denotes hierarchy between } \\
\text { members of Ekpe society }\end{array}$ \\
\hline & & - Used as a fork & It is pointed \\
\hline & Tail $^{1}$ & - Sold to Nigerians & For money \\
\hline & Meat ${ }^{1,4}$ & $\begin{array}{l}\text { - Gives respect between members in the } \\
\text { Ekpe society: prepare and share with other } \\
\text { members }\end{array}$ & Traditional inherited practice \\
\hline & & - Widely used in all ceremonies & Abundant \\
\hline Red-river hog & Teeth $^{3}$ & - For making necklaces: it is traditionally & Tradition and prestige \\
\hline & & $\begin{array}{l}\text { called 'masanga' and is worn by chiets } \\
\text { (Figure 13) }\end{array}$ & $\begin{array}{l}\text { Denotes hierarchy between members of } \\
\text { Ekpe }\end{array}$ \\
\hline & $\operatorname{Skin}^{1,2}$ & $\begin{array}{l}\text { - Prevents miscarriage: boil and use the resulting } \\
\text { concoction for purging pregnant women }\end{array}$ & Medicinal \\
\hline & & - Making of drums & Solid \\
\hline & Head $^{1}$ & - Sold to Nigerians & For money \\
\hline Potto Perodicticus potto & Skull and hands ${ }^{1}$ & - Fortify children and men: scrape and purge & $\begin{array}{l}\text { Believed to transmit its strength to children } \\
\text { and men }\end{array}$ \\
\hline & Skull and limbs ${ }^{1}$ & - Sold to Nigerians & For money \\
\hline & $\begin{array}{l}\text { Right hand and } \\
\text { limb bone }\end{array}$ & $\begin{array}{l}\text { - Treats hernia: boil in water and mix with the } \\
\text { bark of Okan Cylicodiscus gabonensis or burn, } \\
\text { grind and mix with water and herbs locally } \\
\text { called "Tsinabub" (Figure 14). The resulting } \\
\text { concoction is purged by pregnant women and } \\
\text { children }\end{array}$ & Medicinal \\
\hline & & $\begin{array}{l}\text { - Strengthen children: burn, grind, mix with herbs } \\
\text { locally called "Ntemaker" (Figure 15), "Njichondick } \\
\text { or blood leaves" or "Osseleayong leaves" (Figure 16) } \\
\text { and purge }\end{array}$ & Believed to be a strong animal \\
\hline & & $\begin{array}{l}\text { - Strengthen man: burn, grind, cook with } \\
\text { Aframomum melegueta and apply on cuts made } \\
\text { on the body using a razor blade }\end{array}$ & Believed to be a strong animal \\
\hline & & $\begin{array}{l}\text { - Promotes breast milk abundance and fortifies } \\
\text { kids: cook and consume by women who have } \\
\text { just given birth }\end{array}$ & Medicinal \\
\hline & $\mathrm{Skin}^{2,3}$ & - Decoration & Shows the importance of the holder \\
\hline & & - Making of drums & Solid and produces desired sounds \\
\hline & Fur $^{1}$ & - Treat burns: plaster on the skin & The wound dries rapidly \\
\hline Monkeys Cercopithecus spp.; & Skull ${ }^{2}$ & - Sold to Nigerians & For money \\
\hline & $\begin{array}{l}\text { Limbs, head and } \\
\text { young monkeys }{ }^{2}\end{array}$ & - Sold to Nigerians & For money \\
\hline
\end{tabular}


Table 1 Mammals parts used and reasons (Continued)

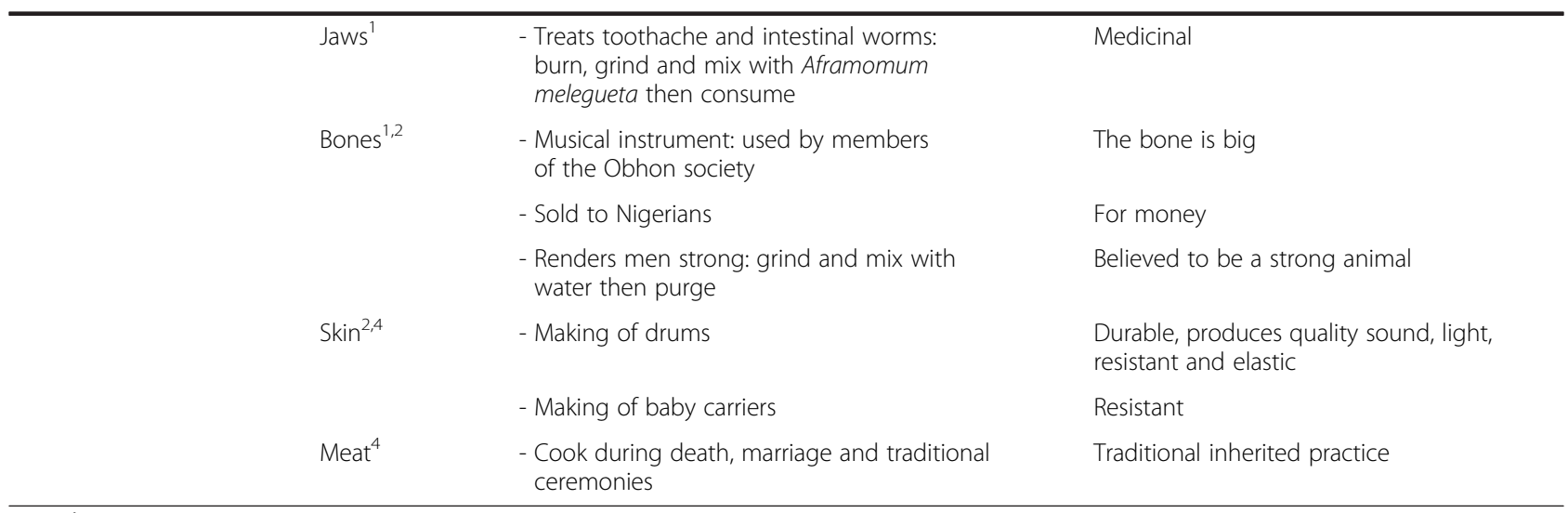

Note: ${ }^{1}$ Animals with food, medicinal and sales values.

${ }^{2}$ Ethnomusical animals and parts used as trophy.

${ }^{3}$ Animals used in decoration and jewelry making.

${ }^{4}$ Magico-religious and multipurpose animals.

species was discovered Sylvisorex pluvialis [28]. In ornithological terms, KNP is reputedly the most diverse lowland site in Africa with a total of 420 bird species recorded so far in 53 families [29-31]. Four species found in the area are considered to be 'rare' including Green-breasted bush-shrike Malaconotus gladiator, White-throated mountain-babbler Lioptilis gilberti, Redheaded rockfowl Picathartes oreas and Yellow-footed honeyguide Melignomon eisentrauti. The African grey parrot Psittacus erithacus is heavily hunted for export trade. In addition, Korup contains 82 reptile and 92 amphibian species, a number of them being endemic to the area. They include three caecilian species, 89 species of frog and toad, two species of tortoises, two species of aquatic turtles, 15 species of lizards, five species of

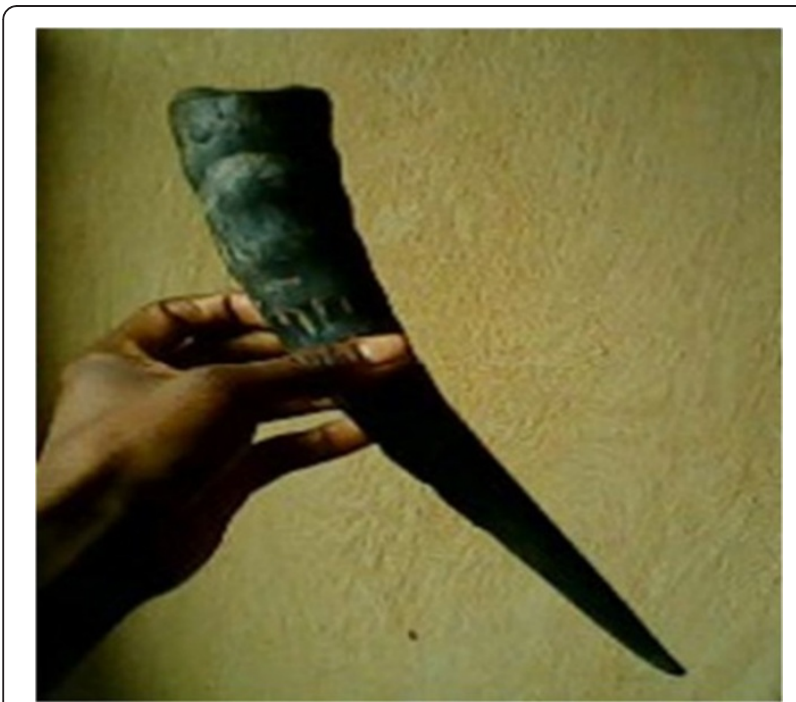

Figure 6 The horn of an African forest buffalo. chameleons, three species of crocodiles and 55 species of snakes. Amphibians listed as endangered or vulnerable include Amietophrynus superciliaris and Nectophryne afra $[32,33]$. Finally, regarding fish, rivers draining Korup and Nkwende are not uniform in their taxonomic composition and diversity. Peculiar to this zone are colonies of stingrays, typically marine snappers Lutjanus sp.; and a jack Trachinotus goreensis, all living over $300 \mathrm{~km}$ from the sea. About 130 species of fish are known from the area [34].

Socio-economically speaking, the social organisation of the village around the NHFR is made of a chief, regent chief (traditional) and other community-based structures. Although important decisions are usually taken in consultation with the traditional council and regent chief, the juju society locally called "Ekpe", remains the most important social institution and governing body in

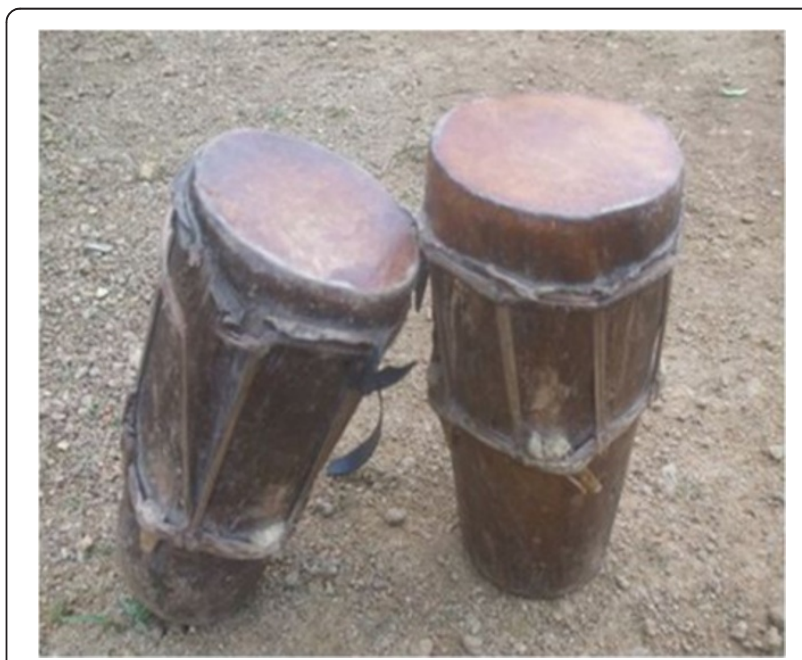

Figure 7 Skin of the blue duiker. 


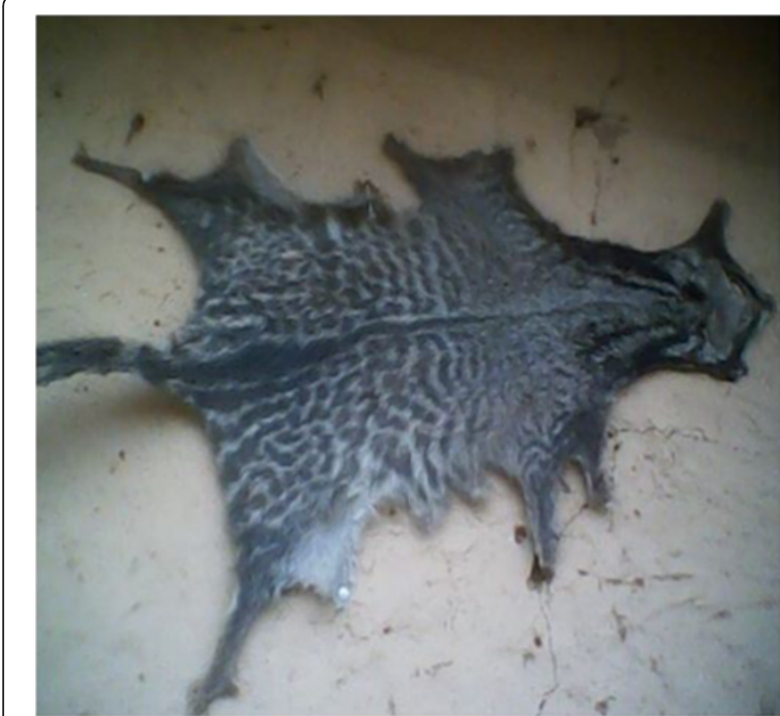

Figure 8 Skin of an African civet.

all villages of the support zone of KNP [35-38]. Community based institutions for the management of natural resources, such as Forest Management Committee (FMC) and other village development associations, exist in the study area. The inhabitants are the Lower Oban people, precisely the Ngunnchang and Obang clans. The common communication language is Pidgin English and the traditional spoken language is the Ejagham.

\section{Socioeconomic profile of Household Respondents (HRs) Distribution of HRs per gender and age}

HRs were dominantly males of the age group 20 to 40 years old (Figure 2). This represents the active age group.

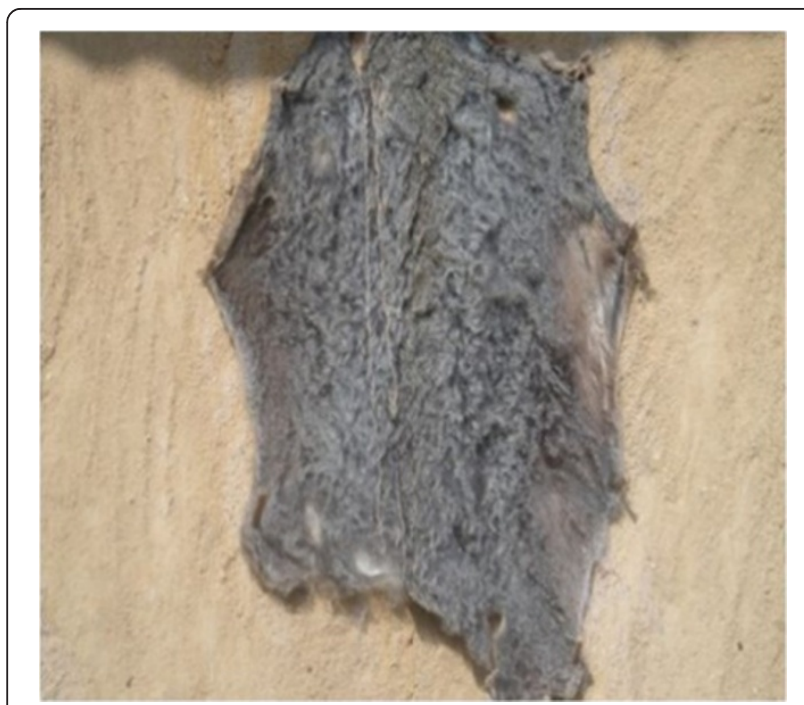

Figure 9 Skin of the flying squirrel.

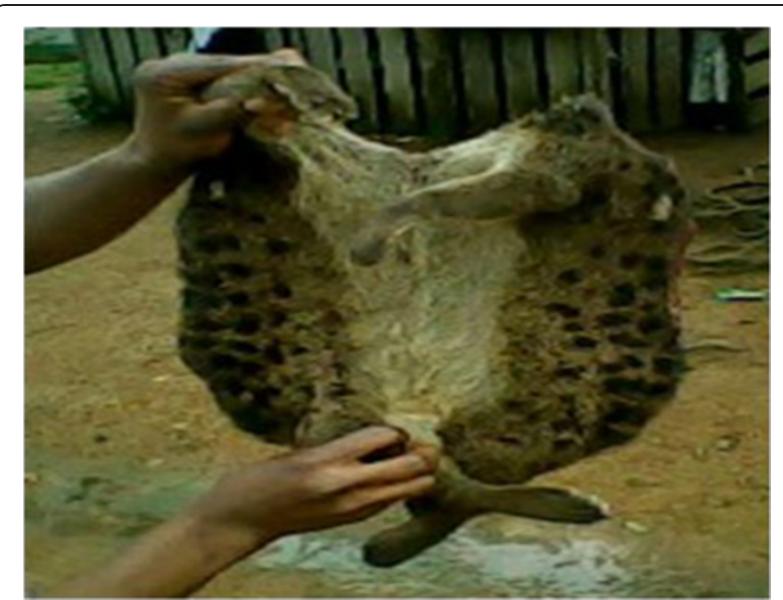

Figure 10 Skin of an African palm civet.

Females were less represented because during interviews, preference was given to males who were considered to be the head of the household, originating from the village, principal hunters and having more knowledge concerning culture and traditions in relation to wildlife.

\section{Distribution of HR by level of education}

About $94 \%$ of HRs went to school. Among these, 53\% have attained the First School Living Certificate (FSLC) at the end of their primary education. This high proportion of HRs with the FSLC is explained by the absence of secondary schools in the area $[39,40]$. About $11 \%$ of HRs have gone to university, i.e. having more than the General Certificate of Education - Advance Level (>ADV), and $6 \%$ were "Illiterates" i.e. have not gone to school at all (Figure 3).

\section{Religion of HRs}

About $85 \%$ of HRs are Christians. Among these, 55\% are Presbyterian Christians (Figure 4). These religions greatly influence the uses of wildlife in the culture and

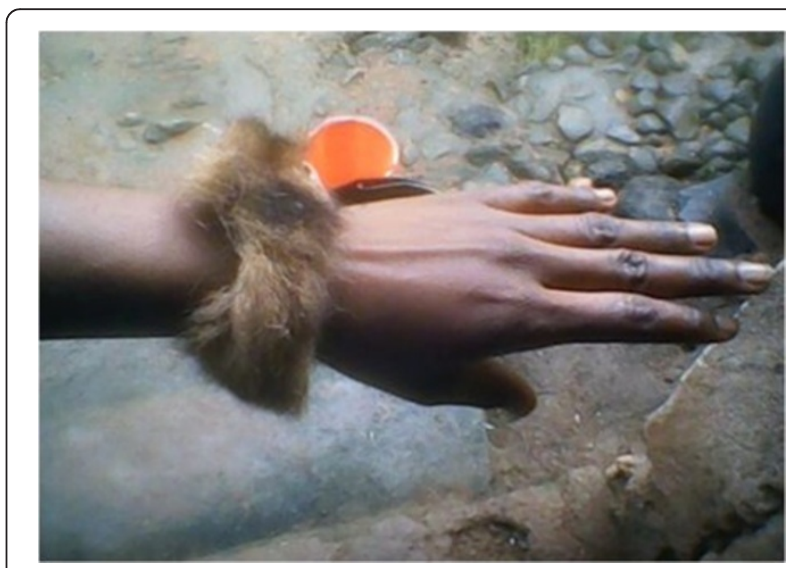

Figure 11 Tail of an African palm civet. 

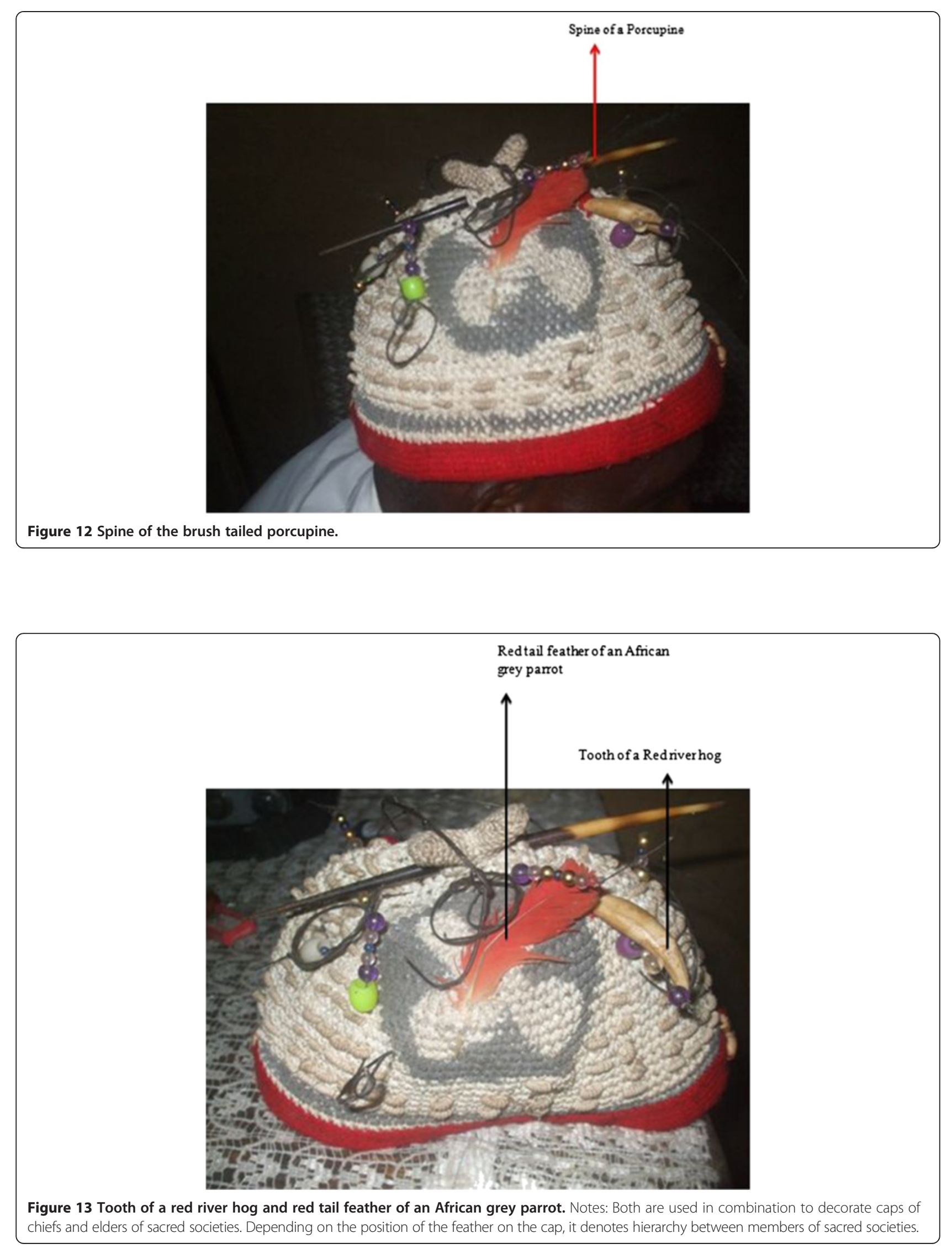
tradition. For example, Jehovah witnesses do not use wildlife because it is prohibited by their religion. On the other hand, non Christians continue to practice traditional rights and respect their tradition. Irrespective of the religious affiliation, HRs use wildlife for traditional purposes in the study area.

\section{Economic activities}

In Cameroon, agriculture represents the primary production sector and it is the main source of employment. It contributes significantly to the Gross Domestic Product of the nation [41]. In the study area, $43 \%$ of HRs practiced only agriculture. Main agricultural products in the study area are cocoa Theobroma cacao, plantain Musa spp.; oil palm Elaeis guineensis, cocoyam Colocasia esculentum, cassava Mahinot spp.; groundnut Arachis hypogea and maize Zea mays. Livestock production is poor in the study area and few goats, chickens, pigs and cattle constitute the main livestock products (as in [37]). People practicing other activities in association with agriculture ("Others") represent $8 \%$ of HRs. About 13\% and $10 \%$ of HRs are students and hunters respectively (Figure 5).

\section{Data collection}

A questionnaire survey was carried out in 126 randomly chosen households from the seven studied villages. Households were chosen by simple random sampling based on the size of the village. It consisted in counting the number of households in each of the seven studied villages, producing a sketch map with the positions and numbers of each household, then numbering them on papers, and then proceeding in a draw without replacement. For villages with households between 0 and 20, a $100 \%$ sampling was performed, between 21 and 50, a 50\% sampling was performed, and greater than 50, a $25 \%$ sampling was performed. Globally, the sampled households in the studied villages ranged between $25 \%$ and $57.1 \%$. HRs were any of the parents or eldest child met at home. Within a household, preference was given to the family head who was considered to be the eldest, the principal hunter, originating from the village, and then supposed to know more concerning the culture and traditions of the village in relation to wildlife. In case of his absence, preference was given to the mother. If both parents were absent, the eldest child was interviewed. In each household, questions were asked to assess their awareness about wildlife used in their culture and as local taboos. Furthermore, self observation and discussions with villagers of all age and sex during meetings, community works and football occasions helped for cross checking. Wildlife species were identified thanks to local names given by HRs, and with reference to the field guide of African mammals [42].

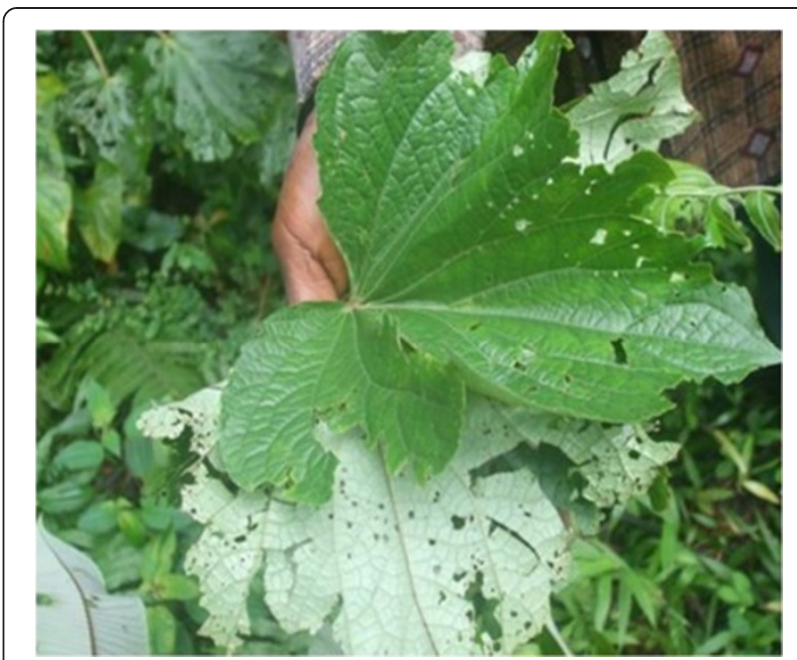

Figure 14 Tsinabup leaf. Notes: Unidentified herb important for mixtures of medicine.

Prior to the realisation of the study, the Chief of the village and the head of the family were consulted and their verbal approval was obtained before any interview. They are aware of the possibility of writing any publication from the data collected and wish to receive a copy of the publication when ready.

\section{Results and discussions}

\section{Traditional uses of wildlife}

Like in other areas of Central Africa, the primary use of wildlife in the study area is for consumption. This is because many people depend on bushmeat as a means to survive during time of hardship (e.g. unemployment and

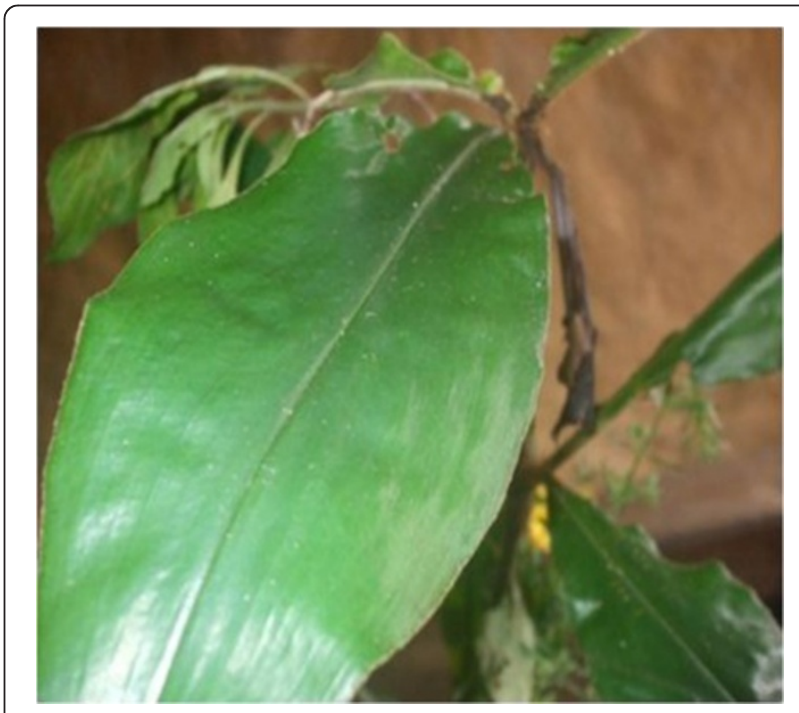

Figure 15 Ntemaker leaf. Notes: Unidentified herb important for mixtures of medicines. 
crop failure), or to gain additional income for special needs (e.g. school fees, festivals and funerals) [43]. This 'safety net' is often more important for the more vulnerable members of the community [15]. Traditional hunting of wildlife in Cameroon for subsistence purposes is not prohibited, though the wildlife law addresses restrictions on the class of species to be harvested, places of harvest, harvest methods, type of weapons and quantity/final use of product [44]. As concerns consumptive uses of wildlife, the most consumed mammal species are Brush-tailed porcupine Atherurus africanus, Blue duiker Cephalophus monticola, Ogilby's duiker Cephalophus ogilbyi, Pangolin Uranamis tetradactyla and monkeys Cercopithecus spp.; (see also [40,45-47]). Consumed reptiles are African rock python Python sebae and Rhinoceros horned viper Bitis nasicornis. The birds consumed are generally large in size such as hornbills Tockus spp.; African grey parrot Psittacus erithacus and Black guineafowl Ageslates niger. As concerns amphibians, toads Bufo spp.; is the most consumed. Lastly, the most consumed fish species are Tilapia Tilapia spp.; Sarotherodon sp.; and mudfish Heterobranchus sp;

Apart from their consumptive uses, $99.7 \%$ of HRs in the study area recognised the effective use of wildlife in their culture and traditions. It was found that 26 mammal species (Table 1, Figures 6, 7, 8, 9, 10, 11, 12, 13, 14, 15, 16), 11 bird species (Table 2, Figures 17, 18, 19), eight reptile species (Table 3, Figures 20, 21, 22), four fish species (Table 4) and two invertebrates (Table 5), representing respectively $50.9 \%, 21.6 \%, 15.7 \%, 7.8 \%$ and $3.9 \%$ of all animal groups, are used in various ways for cultural and traditional purposes.

Some of the uses concerning mammals and reptiles correspond to those described by [49] at the periphery of Rumpi hills forest reserve, and by [18] in the Korup area for mammals only. Some of the uses concerning some of the birds species described in this paper were also identified in $[18,50]$. Some of the uses concerning fish and invertebrates correspond to those described in [51].

Adapted from [22], we classified the above uses of wildlife in the study area in four categories namely:

\section{Animals with food, medicinal and sales values}

This category represented $41.2 \%$ of all uses of wildlife in the study area. This group contains animals like Ogilby's duiker, blue duiker, flying squirrel, potto, chimpanzees (Table 1), African grey parrot, hornbills (Table 2), African rock python, rhinoceros horned viper (Table 3) and all fish (Table 4). According to [19-21]; [48-51], the overlapping of food and medicinal uses is a common finding from India and other parts of the world. Such animals with dual role are important for healing and providing nourishing food items to boost up the immune system [22]. In the present paper they were also considered as a source of income. It should also be noted that the culture regulates the use of species especially those of nutritional and medicinal importance [19-22].

\section{Ethnomusical animals and parts used as trophy}

This category represented $29.2 \%$ of all uses of wildlife in the study area. The skin is the main part used for making

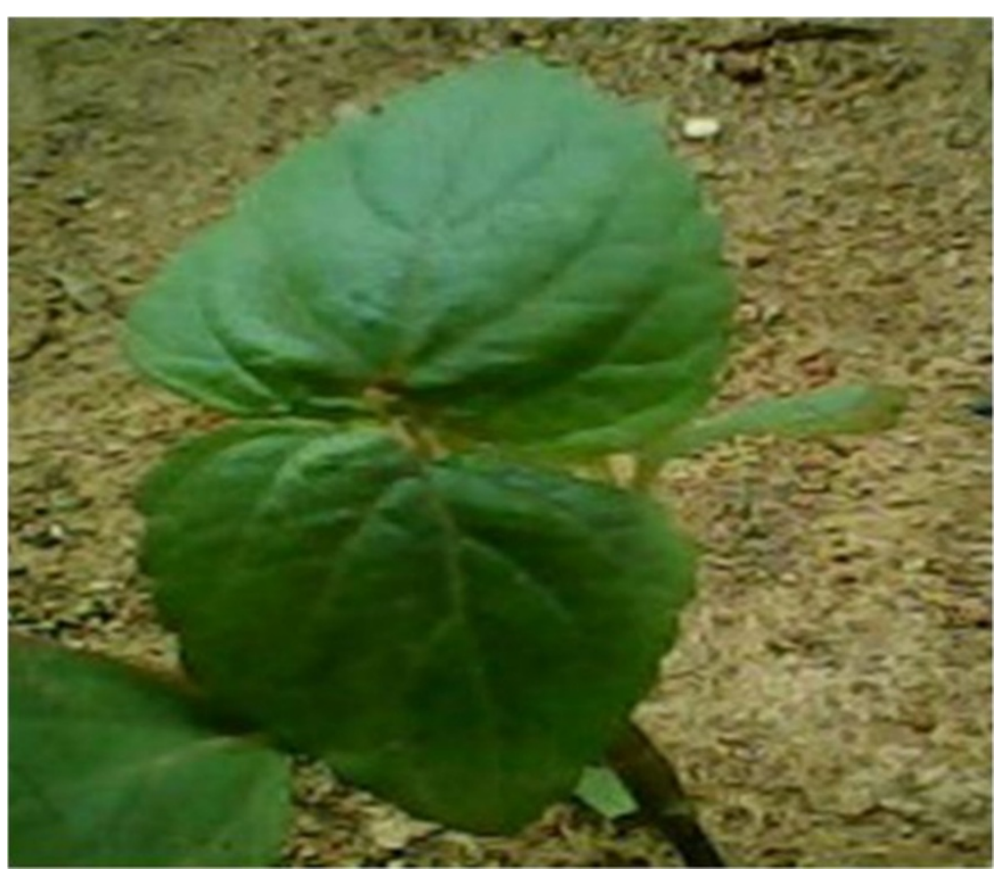

Figure 16 Osselleayong leaf. Notes: Unidentified herb important for mixtures of medicines 
Table 2 Birds parts used and reasons

Animal
Crowned eagle Stephanoaetus
coronatus

coronatus

Hornbills Tockus spp.

.

\section{Barn owl Tyto alba}

Black kite Milvus migrans

Green sunbird Anthreptes rectirostris

African pygmy kingfisher Ispidina picta

African palm Swift Cypsiurus parvus

Palmnut Vulture Gypohierax angolensis

Black guineafowl Agelastes niger

African grey parrot Psittacus erithacus
Part used

Covert feathers $^{3}$

Skull and feathers ${ }^{1}$

White feathers ${ }^{1,3}$

Head and limbs ${ }^{1}$

Skull and feathers ${ }^{1}$

Feathers (white and black) ${ }^{3}$

Head (Figure 17), limbs, feathers and tail $^{1,4}$

Meat $^{4}$

Head and feathers ${ }^{1}$

Feathers $^{3}$

Head and limbs ${ }^{1}$

Meat ${ }^{4}$

Feathers $^{1}$

Limbs and feathers ${ }^{1,3}$

Blood $^{4}$

Skull and feathers

Feathers (Figure 18) 13,3

Feathers $^{3}$

Skull, feathers, tail and limbs'

Red tail feathers ${ }^{1,3,4}$ (Figure 13)

\section{Use and use method}

- Decoration

- Sold to Nigerians

- Decoration

- Wear on caps of members of the Ekpe society and tradi-practitioners

- Sold to strangers and especially to Nigerians

- Sold to Nigerians

- Sold to Nigerians

- Decoration

- Decoration

- Indicators of witches and wizards: used by tradi-practitioners

- Sold to Nigerians

- For protection: dry, grind and apply on cuts made on the body using razor blade

- Sold to Nigerians

- Decorate caps

- Sold to Nigerians

- Consumed only by elders in traditional meals

- Sold to Nigerians

- Sold to Nigerians

- Wear on caps of chiefs of Ekpe

- Apply on body cuts of women during the

"monenkim" dance ceremony

- Sold to Nigerians

- Decoration of traditional dresses

- For protection: burn, grind and apply on cuts

made on the body with a razor blade

- Wear on caps

- Decoration of caps of members of Ekpe

- Sold to Nigerians

- Decorate the masquerades during the Obasinjom traditional dance ceremony

- For protection and decoration: wear on caps of members of Ekpe
Reason(s)

Traditional inherited practice

For money

Decorate Ekpe sorcerers

It is a loyal bird and denotes hierarchy between members of the Ekpe

For money

For money

For money

Denotes hierarchy between members of Ekpe

For Ekpe traditional dance ceremonies

Not revealed

For money

Traditional inherited practice

For money

Denotes hierarchy between members of Ekpe For money

Traditional inherited practice

For money

For money

Denotes hierarchy between members

Believed that the women will dance better

For money

Denotes hierarchy between Ekpe members

Traditional inherited practice

Denotes respect and hierarchy

Denotes hierarchy between Ekpe members

For money

Beautifies the masquerade

Denotes hierarchy between members of Ekpe as it is considered to be a loyal and honored 
bird. The red feathers represent the bloodshed

by ancestors during tribal wars

- Sold to Nigerians

Head

Head and feathers ${ }^{1}$

Great blue turaco Corythaeola cristata

\section{- Sold to Nigerians}

- Sold to Nigerians
- Treats stomachache: grind and mix with the bark of Okan Cylicodiscus gabonensis and Ilomba Pycnanthus angolensis then purge

- Treats whooping cough: burn and mix with medicines and palm kernel oil

- Decoration

- Wear by the Obasinjom masquerade

Blue feather ${ }^{3}$

Feathers $^{1}$

Head $^{1}$

Note: ${ }^{1}$ Animals with food, medicinal and sales values.

${ }^{2}$ Ethnomusical animals and parts used as trophy.

${ }^{3}$ Animals used in decoration and jewelry making.

${ }^{4}$ Magico-religious and multipurpose animals.
For money

For money

Medicinal

For money

Medicinal

Denotes hierarchy between members of Ekpe

Traditional inherited practice

Identifies members of sacred societies

For money

For money 


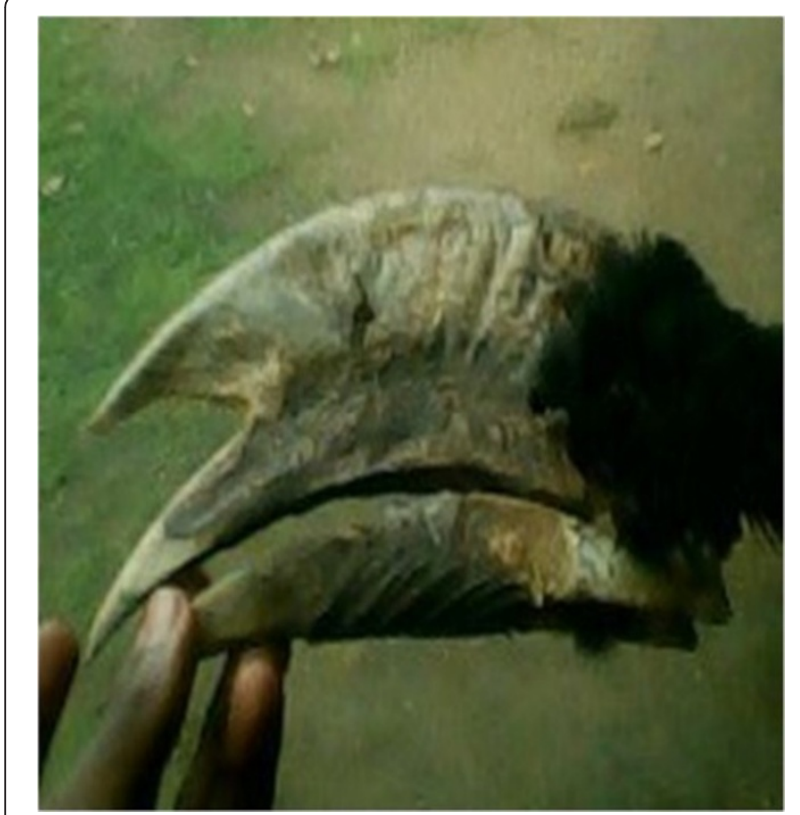

Figure 17 The head of a hornbill.

drums. Animals whose skins are elastic, resistant, durable and non fatty are preferred. Species like blue duiker, Ogilby's duiker, bay duiker (Table 1), African rock python, dwarf crocodiles and Nile monitor (Table 3) are cherished (see also [18]).

\section{Animals used in decoration and jewelry making}

This category represented $21.9 \%$ of all uses of wildlife in the study area. The main parts used are the teeth, feathers of birds and skins. Parts of African civet, leopard, Red river hog (Table 1), African grey parrot, crowned eagle, palmnut vulture (Table 2), African rock python and tortoise (Table 3) are preferred.

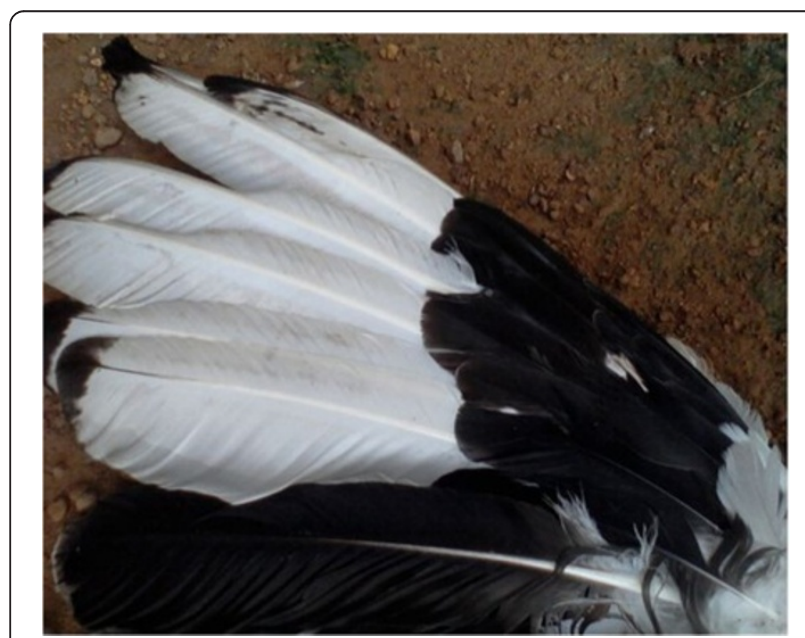

Figure 18 The feathers of a palmnut vulture.

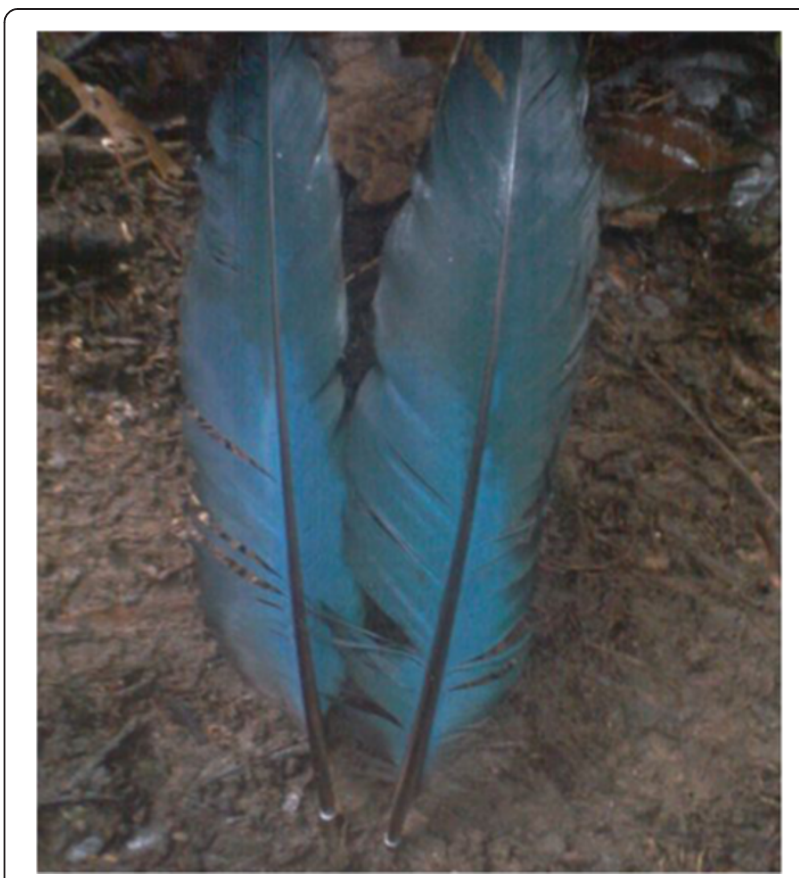

Figure 19 The feathers of a great blue turaco.

\section{Magico-religious and multipurpose animals}

This category represented $7.8 \%$ of all uses of wildlife by both communities. These animals are generally used to communicate with ancestors. Species like Ogilby's duiker, leopard, African civet (Table 1), and crowned eagles (Table 2) are preferred. This category is also represented by animals whose parts serve in various ways such as the buffalo and elephant. Like the Tamang community in Central Nepal, the populations of the study area maintain not only material level relationships with animals but also spiritual relationships [22]. This has been reported in different parts of the world $[52,53]$.

\section{Cultural taboos}

With respect to wildlife use, four types of taboos were identified. These are habitat, species specific, method and segment taboos (see also [54-56]). Among taboo species we found totems that differ according to their origin. On one hand, we found totems which are acquired at birth known as inborn or generation totems, e.g. red river hog, drill, forest elephant and chimpanzee. On the other hand, we found voluntary acquired totems or personal totems such as redcapped mangabey, African rock python and owls. These personal totems are purchased in spiritual markets with the aid of native doctors. These totems play great roles in the conservation of certain species because it is believed that when a totem is killed, a person will die in the village or neighboring village. As 
Table 3 Reptile parts used and reasons

\begin{tabular}{|c|c|c|c|}
\hline Animal & Part used & Use and use method & Reason(s) \\
\hline \multirow{2}{*}{$\begin{array}{l}\text { Nile crocodile Crocodylus } \\
\text { niloticus }\end{array}$} & Skull ${ }^{2}$ & - Decoration & Traditional inherited practice \\
\hline & Skin ${ }^{2}$ & - Making of drums & $\begin{array}{l}\text { Large, durable, elastic and resistant, produce the desired sound } \\
\text { (different from other skins) and contains less fat }\end{array}$ \\
\hline \multirow[t]{2}{*}{ Egyptian cobra Naja haje } & Skin $^{2}$ & - Making of drums & Strong \\
\hline & Head $^{1}$ & - Sold to Nigerians & For money \\
\hline \multirow[t]{5}{*}{$\begin{array}{l}\text { Dwarf crocodile } \\
\text { Osteolaemus tetraspis }\end{array}$} & $\begin{array}{l}\text { Skull and } \\
\text { dung }^{1}\end{array}$ & - Sold to Nigerians & For money \\
\hline & Dung ${ }^{1}$ & - Treat skin problems: rub on the skin & Medicinal \\
\hline & Teeth $^{3}$ & - For making necklaces & Prestige \\
\hline & Skin ${ }^{2,3}$ & - Making of drums & Strong and durable \\
\hline & & - Decoration & Indicates a member of Ekpe \\
\hline \multirow{9}{*}{$\begin{array}{l}\text { African rock python Python } \\
\text { sebae }\end{array}$} & Skull & - Sold to Nigerians & For money \\
\hline & $\begin{array}{l}\text { Fat }^{1} \\
\text { (Figure 20) }\end{array}$ & $\begin{array}{l}\text { - Treat joint pains, snake bite, fire burns, stomachache, swollen fingers, sprain and skin } \\
\text { inflammations: apply on the body part }\end{array}$ & Medicinal \\
\hline & Egg $^{1}$ & - Treats poison: extract the yolk and apply on cuts made on the body with a razorblade & Medicinal \\
\hline & $\begin{array}{l}\text { Bone and } \\
\text { fat }^{1}\end{array}$ & $\begin{array}{l}\text { - Treats waist pains: burn and grind the bones, then mix with the fat and apply on cuts } \\
\text { made on the waist with a razor blade }\end{array}$ & Medicinal \\
\hline & $\mathrm{Skin}^{2,3}$ & - Making of drums & Durable, produces the desired sound, light, large and elastic \\
\hline & & - Making drums of sacred societies & Denotes strength and power \\
\hline & & - Used as carpets by chiefs & For honor \\
\hline & Head $^{1}$ & - Treats snake bites: grind and mix with your blood and consume & Medicinal \\
\hline & & - Sold to Nigerians & For money \\
\hline $\begin{array}{l}\text { Eastern green mamba } \\
\text { Dendroaspis angusticeps }\end{array}$ & Head' & - Ingredient for the composition of the remedy against snake bites & Not revealed \\
\hline \multirow[t]{9}{*}{ Tortoise Kinixys spp.; } & \multirow{5}{*}{$\begin{array}{l}\text { Shell } \\
\text { (Figure 21) }\end{array}$} & - Prevents many diseases: grind and mix with modern medicines and consume & Increases human resistance to diseases \\
\hline & & $\begin{array}{l}\text { - To announce messages/sad news in the village: play using either branches of trees, bones } \\
\text { of blue duiker, elephant, red river hog, gorilla, drill and chimpanzee }\end{array}$ & Inherited traditional practice \\
\hline & & - Decoration & Inherited traditional practice \\
\hline & & - Sold to Nigerians & For money \\
\hline & & - Treats eczema: burn, grind and apply on the skin & Medicinal \\
\hline & \multirow[t]{2}{*}{ Bone $^{1}$} & $\begin{array}{l}\text { - For strength: burn, grind, mix with oil palm and apply on cuts made on the body with a } \\
\text { razor blade }\end{array}$ & Medicinal \\
\hline & & - Treats fractures: tie on the broken leg & Believed to be a strong animal \\
\hline & Blood $^{1}$ & - Treats eczema: apply on the infected part & Medicinal \\
\hline & Tortoise $^{1}$ & - Sold to tradi-practitioners as it is believed to protects man against sorcerers & For money \\
\hline
\end{tabular}


Table 3 Reptile parts used and reasons (Continued)

\section{Nile monitor Varanus \\ Skin 2,3}

niloticus

(Figure 22)

Chest skin ${ }^{2}$ - Making of drums

Rhinoceros horned viper Teeth ${ }^{1,4} \quad$ - Treats breast pains and induces flow of maternal milk: the breast is pierced several times Bitis nasicornis with the tooth
- Treats boyls : pierce the boyl with the tooth

$$
\text { - Used as a blade }
$$

Skull ${ }^{1,4} \quad$ - Protect man against sorcerers: grind and mix with oil palm and apply on cuts made on the body with a razor blade

- Sold to Nigerians

Skin $^{2} \quad$ - Making of drums

Head ${ }^{1} \quad$ - Dry and sell to tradi-practitioners and Nigerians
Durable, resistant, light, elastic and produces good sound

\section{Denotes power}

Solid

Inherited traditional practice

Medicinal

Inherited traditional practice

Usually considered as a witchcraft animal

For money

Durable, large, light, elastic and produces quality sound. Also, it does not contain fat

For money

Note: ${ }^{1}$ Animals with food, medicinal and sales values

${ }^{2}$ Ethnomusical animals and parts used as trophy.

${ }^{3}$ Animals used in decoration and jewelry makin

${ }^{4}$ Magico-religious and multipurpose animals. 


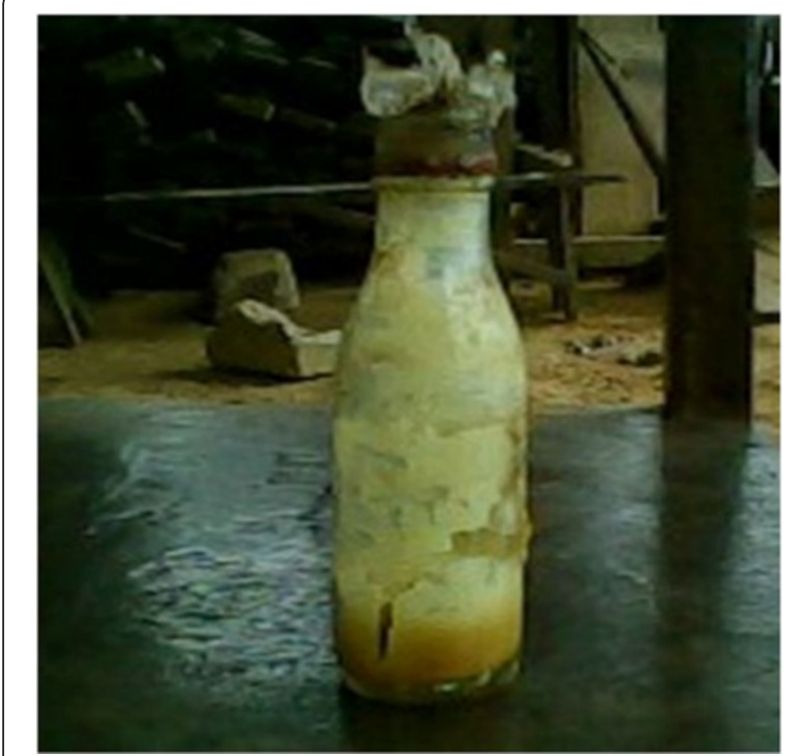

Figure 20 Fats extracted from the African rock pythons skin.

concerns habitat taboos, sacred forests exist in the study area. According to [13] they are crucial conservation sites characterised by high biodiversity. They varied between one and four sites per village. The four locally identified sacred forests are Ekpe, Mawooh, Obhon and Amgbu sacred forests. Habitat taboo was the most common in the study area and seems to be the most known and respected form of taboo in Africa [55]. The restriction to use gamaline and toxic products for fishing by the village traditional councils was the main method taboo. Segment taboos are manifested by the

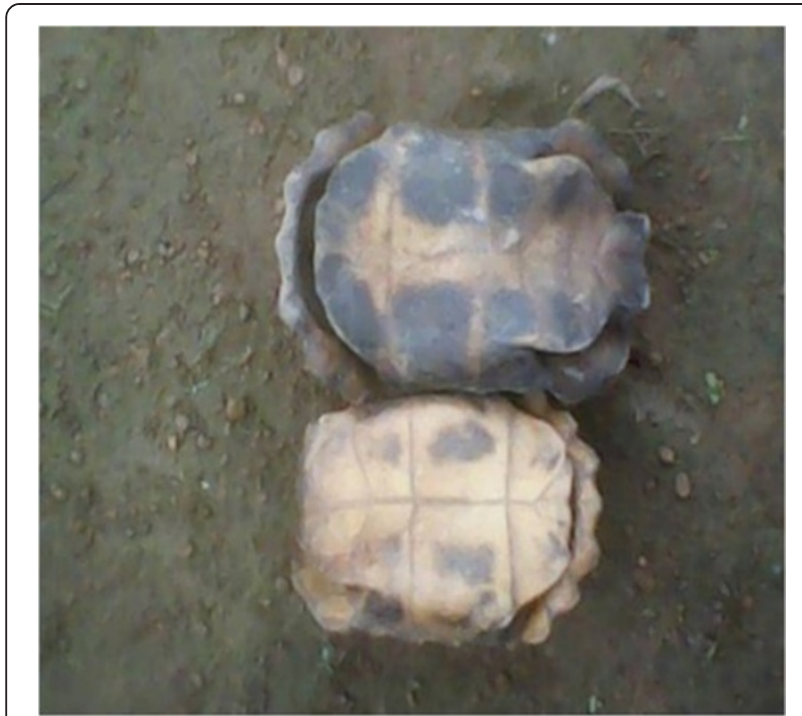

Figure 21 The shells of tortoises.

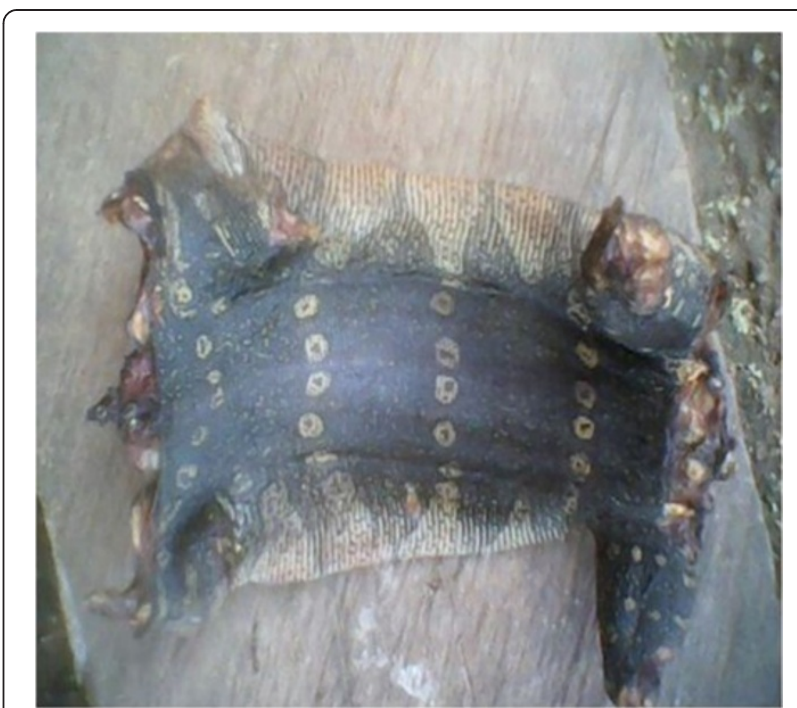

Figure 22 The skin of a Nile monitor.

restriction of women and children from consuming certain animals such as Red river hog (according to $15.6 \%$ of HRs), Snakes (according to $8.5 \%$ of HRs) and most primates. It is however important to note that threats to wildlife is real. An evaluation of the perceptions of HRs on the use level of wildlife showed that, wildlife use for cultural and traditional purposes is disappearing progressively (according to $96.7 \%$ of HRs). This trend was mainly because of the scarcity of wildlife (65.3\% of HRs) and the loss of culture among the youths (12.5\% of HRs).

\section{Conclusion}

Literature on efficacy of indigenous knowledge offers huge hopes to conservation success [57-60]. Like other

\section{Table 4 Fish parts used and reasons}

\begin{tabular}{|c|c|c|c|}
\hline Animal & Part used & Use and use method & Reason(s) \\
\hline \multirow[t]{2}{*}{$\begin{array}{l}\text { Sardine fish } \\
\text { Sardina sp.; }\end{array}$} & Young ${ }^{1}$ & $\begin{array}{l}\text { - Treats cardiovascular illnesses: } \\
\text { cook with plenty of oil palm } \\
\text { and consume }\end{array}$ & Medicinal \\
\hline & Flesh $^{1}$ & $\begin{array}{l}\text { - Treats cardiovascular illnesses: } \\
\text { consume }\end{array}$ & Medicinal \\
\hline $\begin{array}{l}\text { Electric catfish } \\
\text { Malapterurus } \\
\text { electricus }\end{array}$ & Flesh $^{1}$ & $\begin{array}{l}\text { - Treats cardiovascular illnesses: } \\
\text { consume }\end{array}$ & Medicinal \\
\hline $\begin{array}{l}\text { Mud sucker Labeo } \\
\text { coubie }\end{array}$ & Flesh $^{1}$ & $\begin{array}{l}\text { - Treats cardiovascular illnesses: } \\
\text { cook and consume }\end{array}$ & Medicinal \\
\hline $\begin{array}{l}\text { Giant mud fish } \\
\text { Heterobranchus sp.; }\end{array}$ & Flesh $^{1}$ & $\begin{array}{l}\text { - Treats cardiovascular illnesses: } \\
\text { cook and consume }\end{array}$ & Medicinal \\
\hline
\end{tabular}

Note: ${ }^{1}$ Animals with food, medicinal and sales values.

${ }^{2}$ Ethnomusical animals and parts used as trophy.

${ }^{3}$ Animals used in decoration and jewelry making.

${ }^{4}$ Magico-religious and multipurpose animals. 
Table 5 Invertebrates parts used and reasons

\begin{tabular}{|c|c|c|c|}
\hline Animal & Part used & Use and use method & Reason(s) \\
\hline \multirow[t]{6}{*}{ Snails Achatina sp.; } & \multirow[t]{5}{*}{ Shell ${ }^{1,2,3}$} & - Formerly used a drinking cup & Drinking cups did not exist before \\
\hline & & - Musical instrument & Produces a particular unique sound \\
\hline & & - Decoration & Traditional inherited practice \\
\hline & & $\begin{array}{l}\text { - Treats waist problems: grind and mix with leaves } \\
\text { of Ageratum cornisoides and apply on cuts made } \\
\text { on the body with a razor blade }\end{array}$ & Medicinal \\
\hline & & - Key holders & Inherited traditional practice \\
\hline & $\begin{array}{l}\text { Sticky/slippery liquid from } \\
\text { the body }\end{array}$ & $\begin{array}{l}\text { - Eases birth (reduces labour pains): mix with water } \\
\text { and purge by pregnant women }\end{array}$ & $\begin{array}{l}\text { Believed to make the foetus slide } \\
\text { out easily }\end{array}$ \\
\hline \multirow[t]{2}{*}{$\begin{array}{l}\text { Crabs Emerita sp.; } \\
\text { Blepharipoda sp.; }\end{array}$} & Carapace $^{1}$ & $\begin{array}{l}\text { - Treats eczema: burn and mix the ash with Tsinabup } \\
\text { leaves and apply on the skin }\end{array}$ & Medicinal \\
\hline & Chest $^{1}$ & $\begin{array}{l}\text { - Prevents children from watering the bed at night: } \\
\text { consume by children }\end{array}$ & Medicinal \\
\hline
\end{tabular}

Note: ${ }^{1}$ Animals with food, medicinal and sales values.

${ }^{2}$ Ethnomusical animals and parts used as trophy.

${ }^{3}$ Animals used in decoration and jewelry making.

${ }^{4}$ Magico-religious and multipurpose animals.

indigenous populations, the Obang and Ngunnchang populations possess rich ethnozoological knowledge. They have accumulated knowledge on the uses of several species of wildlife which were classified into animals with "food, medicinal and sales values", "ethnomusical animals and parts used as trophy", animals used in "decoration and jewelry making" and "magico-religious and multipurpose animals" based on the method of use and the reason attributed by HRs (see also [22]). Body parts such as the skin are used in making musical instruments such as drums. Flesh cooked with plantains and palm oil is used for liberation ceremonies and communication with ancestors. Bones are used for strengthening; feathers are used to denote hierarchy between members of sacred societies and many others are used for medicines. Plants like Ageratum cornisoides, Aframomum melegueta and Elaeis guineensis happen to be very important for mixtures of medicines and thus play important medicinal roles (see also [50]). Both communities believe in species specific, habitat, method and segment taboos which, if respected duly, are great conservation measures. They are traditional practices known to have promising potential for enhancing sustainable resource use (see also [61]). To evaluate the level of respect of the culture in other to ascertain the role played by traditional knowledge and taboos in conservation, it is imperative to know the level of loss of the culture (acculturation) as the conservation of not only biodiversity but also cultural diversity is necessary for development [22]. Strategies to fight against threats to wildlife should thus be defined taking also into consideration traditional knowledge and taboos. High priority should be given to reconciling conservation of species with high values for local communities and human needs.

Competing interests
The authors declare that they have no competing interests.

\section{Authors' contributions}

All authors conceived the study. KSB drafted and revised the manuscript. FFMA and BCN conducted the field study, performed the data analysis and drafted the manuscript. All authors read and approved the final manuscript.

\section{Acknowledgements}

The study was carried out thanks to the financial support from the VolkswagenFoundation, under the "Africa initiative - Knowledge for Tomorrow: Cooperative Research Projects in Sub-Saharan Africa", through the project «Managing Forest wildlife for Human Livelihoods in the Korup-Oban Hills region, West-Central Africa». Special thanks to the population of the studied villages for their hospitality and valuable contribution to the research

Received: 4 June 2014 Accepted: 26 November 2014

Published: 7 January 2015

\section{References}

1. Naughton-Treves $L$, Weber $W$ : Human dimensions of the African rainforest. In African rainforest ecology and conservation. Edited by Weber W, White LT, Vedder A, Naughton-Treves L. New Haven: Yale University press; 2001:30-43.

2. Stuart SN, Adams RJ, Jenkins MD: Biodiversity in sub-saharan Africa and its islands: conservation, management and sustainable use. In IUCN occasional papers 6. Gland, Switzerland.1990.

3. Doumenge C: Atlas pour la conservation des forêts d'Afrique. In UICN, France editions Jean Pières de Monza Paris. 1996:310.

4. Doumenge C: Forest diversity, distribution and dynamics in the Itombwe mountains, South - kivu. Congo Democratic Repub Mt Resour Dev 1998, 18(3):249-264.

5. Doumenge C, Garcia JE, Gartlan S, Langrand O, Ndinga A: Conservation de la biodiversité forestière en Afrique centrale Atlantique: Le réseau d'aires protégées est -il adéquat? Bois Forêts Tropiques 2001, 268:5-27.

6. Wilkie DS, Carpenter JF: Bushmeat hunting in the Congo Basin: an assessment of impacts and options for mitigation. Biodiv Conserv 1999, 8:927-955.

7. Food and Agricultural Organisation: Resources assessment of Non Timber Products experience and biometric principles. 2001:109. 
8. Mbolo M: La collecte et l'analyse des données statistiques sur les produits forestiers non ligneux: Une étude pilote au Cameroun. In. 2002:137.

9. Robinson JG, Bennett EL: Carrying capacity limits to sustainable hunting in tropical forests. In Hunting for sustainability in tropical forests. Edited by Robinson JG, Bennett EL. New York: Columbia University Press; 2000:13-30.

10. World Conservation Monitoring Centre: United Nations list of national parks and protected areas. Gland: IUCN; 1994

11. Adams WM: Green development: environment and sustainability in the third world. London: Routledge; 2001.

12. Sillitoe $P$, Alshawi LAA, Al-Amir HAK: Challenges to conservation: land use change and local participation in the AIReem Biosphere Reserve, West Qatar. J Ethnobiol Ethnomed 2010, 6:28. http://www.ethnobiomed.com/ content/6/1/28.

13. Duncan WT, McCauley JT, Bromley WA, Mbenchum FT: Korup ethnobotany survey. Final report. Weyside park, Godalming Surrey: WWF Panda house; 1989:154.

14. de Merode E, Homewood K, Cowlishaw G: Wild resources and livelihoods of poor households in Democratic Republic of Congo. In ODI Wildlife Policy Briefing No.1. 2003.

15. Kideghesho JR: Co-existence between the traditional societies and wildlife in western Serengeti, Tanzania: its relevancy in contemporary wildlife conservation efforts. Biodiver Conserv 2008, 21:

16. Hobbs JJ: Guidelines for the involvement of nomadic pastoralists in conservation and development. In Nomadic societies in the Middle East and North Africa: entering the 21st century. Edited by Chatty D. Leiden: Brill Publishers; 2006:785-799.

17. Mwihomeke ST, Msangi TH, Mabula CK, Ylhäisi J, Mndeme $\mathrm{KCH}$ : Traditionally protected forests and nature conservation in the North Pare mountains and Handeni district, Tanzania. J East Afr Nat Hist 1998, 87(1 and 2):279-290

18. Bobo KS, Ntumwel CB: Mammals and birds for cultural purposes and related conservation practices in the Korup area, Cameroon. Life Sci Leaflets 2010, 9:226-233.

19. Kakati LN, Doulo V: Indigenous knowledge system of zootherapeutic use by Chakhesang tribe of Nagaland, India. J Hum Ecol 2002, 13:419-423

20. Solovan A, Paulmurugan R, Wilsanand V, Singh RAJA: Traditional therapeutic uses of animals among tribal populations of Timil Nadu. Ind J Trad Know 2004, 3:198-205.

21. Jamir NS, Lal P: Ethnozoological practices among Naga tribes. Ind J Trad Know 2005, 4:100-104

22. Lohani U: Man-animal relationships in Central Nepal. J Ethnobio Ethnomed 2010, 6:31

23. Alves RRN: Relationships between fauna and people and the role of ethnozoology in animal conservation. Ethnobiol Conserv 2012, 1(2):1-69.

24. Bobo KS, Weladji RB: Wildlife and land use conflicts in the Mbam and Djerem conservation region, Cameroon: status and mitigation measures. Hum Dimen Wild 2011, 16(6):445-457.

25. Alves RRN, Albuquerque UP: Ethnobiology and conservation: why do we need a new journal? Ethnobiol Conserv 2012, 1:1-3.

26. Ndeh ADR, Mbah B, Dzikouk G: Ornithological surveys of Nkwende Hills, Bakossi Mt. UFA (11-001 and 11-002); for biodiversity conservation and priority settings in the Cameroon-Nigeria Transboundary. Birdlife Int 2002, 44:

27. Zimmermann L: A comparative study of growth and mortality of trees in Ceasalp dominated lowland African rainforest at Korup, Cameroon. 2000.

28. Hotterer RE, Schlitter DA: Shrews of Korup National Park, Cameroon, with the description of a new Sylvorex (Mammalia: Soricidae). 1991.

29. Rodewald PG, Dejaifve PA, Green AA: The birds of Korup National Park and Korup project area, South West Province, Cameroon. Bird Conserv Intern 1994, 4:1-68.

30. Bobo KS, Waltert M, Fichtler M, Mühlenberg M: New bird records for the Korup project area, Southwest Cameroon. Malimbus 2005, 27:13-18.

31. Bobo KS, Njie FM, Mbeng SE, Mühlenberg M, Waltert M: Baumann's Greenbul Phyllastrephus baumanni, new to Cameroon. Short Notes. Malimbus 2007, 29:130-132.

32. Lawson DP: Inventory and status of Herpetofauna of Korup Rainforest National Park, Cameroon. In Report to the Korup Project. 1992

33. Lawson DP: The reptiles and amphibians of the Korup National Park project, Cameroon. Herpetol Nat Hist 1993, 1:27-90.
34. Reid GM: The living waters of Korup rainforest: a biological survey report and recommendations with emphasis on fish and fisheries. In WWF report 3206-A8:1. Gland: World Wildlife Fund; 1989.

35. Devitt P: The people of Korup project area: report on phase one of the socio-economic survey. WWF-UK; 1988

36. Butcher C: Village information database: a survey of the villages in the support zone of Korup project. In Korup project, Cameroon. 1997.

37. Vabi M: Socio-economic surveys of human use inside and within $3 \mathrm{~km}$ of Korup National Park. In WWF-CPO Activities Report. 1999.

38. Malleson R: Forest livelihoods in SW Province, Cameroon: an evaluation of the Korup experience. University College London; 2000. Submitted for the Degree of Ph.D. Department of Anthropology.

39. Ngalim OY: Revenue components and conflicts in the use of natura resources in the peripheral zone North-east of the Korup National Park In Memoire FASA/UDs. 2011:93.

40. Ntumwel BC: Contribution of dung decay rates to the estimation of densities of duikers and the ethnobiology of mammals and birds in the Korup National Park. In Internship report/ FASA/UDs. 2010:49.

41. Dewbre J, BorotdeBattisti A: Agricultural progress in Cameroon, Ghana and Mali: why it happened and how to sustain it. OECD Food Agric Fish Working Papers 2008, 9:60.

42. Kingdon J: The Kingdon field guide to African mammals. San diego: Academic Press; 1997:496.

43. Fa JE, Brown D: Impacts of hunting on mammals in African tropical moist forests: a review and synthesis. Mammal Rev 2009, 39:231-264.

44. Djeukam R: The wildlife law as a tool for protecting threatened species in Cameroon. In A report to MINFOF, Cameroon. 2007:34

45. Kamgaing TOW: Chasse villageoise et contribution a l'élaboration d'un modèle de prélèvement durable pour Cephalophus monticola en périphérie nord-est du parc national de Korup, sud-ouest Cameroun. In Mémoire F.A.S.AVUds. 2011:119.

46. Moute $\mathrm{A}$ : Contribution à l'élaboration des stratégies pour une gestion durable de la faune mammalienne sauvage en périphérie nord-est du Parc National de Korup, Sud-ouest Cameroun. In Mémoire FASA/Uds. 2010:83

47. Ndengue MLS: Evaluation du statut de conservation des primates diurnes à la périphérie nord-est du Parc National de Korup, Sud-ouest Cameroun. In Mémoire F.A.S.A/Uds. 2011.

48. Brown MW: The roles of wild animals in rural households of the Korup National Park support zone: Women perspectives. In Report to the Korup project. 1996:13.

49. Lauren E: Wildlife utilization survey of villages surrounding the Rumpi hills forest reserve. In Report to the Korup project. 1992:59.

50. Bobo KS, Ntumwel BC, Nganmegne FN, Fosso LC, Mekontchou CG: Sacred plants and animals in the Batoufam and Bansoa communities in west Cameroon. Life Sci Leaflets 2011, 18:684-689.

51. Reid GM: The living waters of Korup rainforest: a hydrobiological survey report and recommendations, with emphasis on fish and fisheries. In Report to the Korup project. 1989:72.

52. Alves RRN, Léo Neto NAL, Santana GG, Vieira WLS, Almeida WO: Reptiles used for medicinal and magic religious purposes in Brazil. Appl Herpetol 2009, 6:257-274

53. Solanki GS, Chutia P: Ethnozoological and sociocultural aspects of Monpas of Arunachal Pradesh. J Hum Ecol 2004, 15:251-254.

54. Colding J, Folke C: The relations among threatened species, their protection and taboos. Conserv Ecol (Online) 1997, 1:6.

55. Colding J, Folke C: Social taboos: "invisible" systems of local resource management and biological conservation. Ecol App/ 2001, 11:584-600

56. Azah MM: A socio-economic study on the feasibility of a community wildlife management concept in the periphery zone northeast of the Korup National Park. In Memoire FASA UDs. 2010:75.

57. Berkes F, Colding J, Folke C: Rediscovery of traditional ecological knowledge as adaptive management. Ecol Appl 2000, 10(5):1251-1262.

58. Berkes F: Rethinking community-based conservation. Conserv Biol 2003, 18(3):621-630

59. Becker CD, Ghimire K: Synergy between traditional ecological knowledge and conservation science supports forest preservation in Ecuador. Conserv Ecol 2003, 8(1):1. (Online) URL: [http://www.ecologyandsociety.org/ vol8/iss1/art1/] 
60. Moller H, Berkes F, Lyver PO, Kislalioglu M: Combining science and traditional ecological knowledge: monitoring populations for co-management. Ecol Soc 2004, 9(3): [online]. Accessed 22 May 2006.

61. Kideghesho JR: The potentials of traditional African cultural practices in mitigating overexploitation of wildlife species and habitat loss: experience of Tanzania. Int J Biodivers Sci Ecosyst Serv Manage 2009, 5:83-94.

doi:10.1186/1746-4269-11-2

Cite this article as: Bobo et al:: Wildlife use and the role of taboos in the conservation of wildlife around the Nkwende Hills Forest Reserve; South-west Cameroon. Journal of Ethnobiology and Ethnomedicine $201411: 2$

\section{Submit your next manuscript to BioMed Central and take full advantage of:}

- Convenient online submission

- Thorough peer review

- No space constraints or color figure charges

- Immediate publication on acceptance

- Inclusion in PubMed, CAS, Scopus and Google Scholar

- Research which is freely available for redistribution 